ARTIGO

\title{
EDUCAÇÃO DE EXCEPCIONAIS NO PERIÓDICO MENSAGEM DA APAE (1963-1973): UMA PEDAGOGIA PARA A MODELAGEM E AJUSTAMENTO SOCIAL
}

\author{
GIOVANI FERREIRA BEZERRA ${ }^{1}$ \\ ORCID: https://orcid.org/0000-0002-4710-3897
}

ALESSANDRA CRISTINA FURTADO ${ }^{2}$

ORCID: https://orcid.org/0000-0002-6084-2299

\begin{abstract}
RESUMO: Neste artigo, discute-se a forma como era representada e tematizada a educação de excepcionais (hoje, pessoas com deficiência intelectual), sob o influxo da Associação de Pais e Amigos dos Excepcionais (Apae), entre as décadas de 1960 e 1970 no Brasil. Para tanto, toma-se o impresso periódico Mensagem da Apae como fonte e objeto de pesquisa, em sua primeira fase de existência (19631973), na perspectiva da Nova História Cultural. Pela organização material e textual do impresso, evidencia-se o investimento discursivo como forma de legitimar uma identidade institucional e justificar o trabalho das Apaes com esse público, mediante uma perspectiva pedagógica institucional que visava (re)habilitar, treinar e ajustar o excepcional à sociedade, imputando-lhe uma ocupação laboral, em caráter semiprofissional, desqualificado e repetitivo. Desse modo, a educação ofertada não era um processo consistente de profissionalização, muito menos de escolarização, mas sim uma forma de higiene social. Logo, o foco não estava em formar o cidadão, e, sim, impedir a emergência do delinquente, bem como liberar os pais e familiares que se ocupavam do excepcional para que estes pudessem trabalhar e serem produtivos, com vistas a se impedir a perturbação do progresso nacional e a fomentar uma suposta harmonia do tecido social, em um contexto marcado pelo tecnicismo político-educacional e pela ditadura civil-militar.
\end{abstract}

Palavras-chave: História da Educação Especial, Associação de Pais e Amigos de Excepcionais, Impresso Periódico.

\footnotetext{
1 Universidade Federal da Grande Dourados, Faculdade de Educação (UFGD/FAED). Dourados, MS, Brasil. <giovanibezerra@ufgd.edu.br>

2 Universidade Federal da Grande Dourados, Faculdade de Educação (UFGD/FAED). Dourados, MS, Brasil. <alessandrafurtado@ufgd.edu.br>
} 


\title{
EDUCATION OF INTELLECTUALLY DISABLED PEOPLE IN THE PERIODICAL MENSAGEM DA APAE (1963-1973): A PEDAGOGY FOR MODELING AND SOCIAL ADJUSTMENT
}

\begin{abstract}
This article discusses how the education of intellectual disabled people was represented and thematized, under the influence of Associação de Pais e Amigos dos Excepcionais (Apae), between the 1960s and 1970s in Brazil. To this end, the printed periodical Mensagem da Apae is taken as the source and object of research, in its first phase (1963-1973), from the perspective of the New Cultural History. By the material and textual organization of the periodical, we can perceive the discursive investment as a way to legitimize an institutional identity and justify Apae's work to this public. In an institutional pedagogical perspective that aimed to (re)habilitate, train, and adjust intellectually disabled people to society, offering them semiprofessional, non-qualified, and repetitive jobs. Thus, the education offered was not a consistent process of professionalization, much less schooling, but a form of social hygiene. Thus the focus was not on forming citizens but rather to prevent the emergence of offenders, as well as to free parents and caretakers to work and be productive, preventing the disruption of national progress and foster an alleged harmony of the social fabric, in particular a context marked by political-educational technicism and civil-military dictatorship.
\end{abstract}

Keywords: History of Special Education, Associação de Pais e Amigos de Excepcionais, Periodical Press.

\section{EDUCACIÓN DE EXCEPCIONALES EN EL PERIÓDICO MENSAGEM DA APAE (1963-1973): UNA PEDAGOGÍA PARA EL MODELADO Y AJUSTE SOCIAL}

RESUMEN: Este artículo analiza cómo la educación de los excepcionales (hoy en día las personas con discapacidad intelectual) fue representada y tematizada, bajo la influencia de la Associação de Pais e Amigos dos Excepcionais (Apae), entre las décadas de 1960 y 1970 en Brasil. Por lo tanto, la publicación periódica Mensagem da Apae se toma como fuente y objeto de investigación, en su primera fase de existencia (1963-1973), desde la perspectiva de la Nueva Historia Cultural. Mediante la organización material y textual de la impresión, la inversión discursiva se evidencia como una forma de legitimar una identidad institucional y justificar el trabajo de las Apaes con este público, a través de una perspectiva pedagógica institucional que tenía como objetivo (re) habilitar, capacitar y ajustar el excepcional a la sociedad, imputándole una ocupación laboral de carácter semiprofesional, descalificada y repetitiva. Por lo tanto, la educación ofrecida no fue un proceso constante de profesionalización, tampoco de escolarización, sino una forma de higiene social. Entonces, el foco no estaba en formar al ciudadano; sino en impedir la aparición del delincuente, así como en liberar a los padres y familiares que se ocuparon del excepcional para que pudieran trabajar y ser productivos, a fin de evitar la interrupción del progreso nacional y fomentar una supuesta armonía del tejido social, en un contexto marcado por el tecnicismo político educativo y por la dictadura cívico militar.

Palabras clave: Historia de la Educación Especial, Associação de Pais e Amigos dos Excepcionais, Impreso Periódico. 


\section{INTRODUÇÃO}

Este artigo tem como objetivo abordar a forma como era tematizada e representada a educação de "excepcionais", sob o influxo das Associações de Pais e Amigos dos Excepcionais (Apaes) e de sua Federação Nacional ${ }^{4}$, entre as décadas de 1960 e 1970, no Brasil, a partir da perspectiva historiográfica da Nova História Cultural. Particularmente, dessa vertente historiográfica são explorados os pressupostos da história do livro, da leitura e dos impressos em geral, conforme vêm sendo difundidos e desenvolvidos por Chartier (1990, 2002, 2007), tendo-se por base o conceito de representação desse mesmo autor (CHARTIER, 1990). Perante as demandas da educação escolar na atualidade, bem como pelo avanço da própria historiografia da educação, torna-se fundamental entendermos como se constituíram as representações em torno das práticas educativas destinadas a tais sujeitos, então considerados como retardados. Afinal, essas práticas apresentam continuidades e rupturas com a forma hodierna de se pensar e se praticar a educação das pessoas com deficiência intelectual, conforme a nomenclatura mais recente ${ }^{5}$.

Tais considerações já nos colocam diante da necessidade de tomarmos essa história como problema de análise, haja vista ainda ser pouco abordada no conjunto das pesquisas brasileiras no campo da História da Educação (BEZERRA; FURTADO, 2017). Como já demonstrado em outros trabalhos, continuam incipientes os estudos acerca da história das Apaes e, também, de sua Federação, por se privilegiarem outros assuntos ou temporalidades menos recuadas historicamente no tocante ao hoje denominado movimento apaeano. Em revisão bibliográfica, a tese de Silva (2017), quanto à temática das Apaes e de sua Federação, registra que:

A produção acadêmica nos mostra que a área majoritária dos estudos está relacionada à área da psicologia e educação, campos científicos que se dedicam às dimensões educativa e psicológica da deficiência. A maioria dos trabalhos foi realizada em nível de mestrado e nas universidades públicas, como a Universidade de Brasília e a Universidade Estadual do Oeste do Paraná.

A produção científica pode ser contemplada em três eixos [...]: a) propostas educacionais; b) educação física e c) educação profissional. O primeiro eixo traz subsídios para compreender quais as concepções e os fundamentos das propostas educacionais da Fenapaes. O segundo trata da disciplina educação física como componente complementar do currículo das Apaes. E o terceiro diz respeito à modalidade de ensino educação profissional articulada à qualificação para o trabalho.

[...]três pesquisas foram desenvolvidas no final do século XX. [...]. Outras onze pesquisas foram desenvolvidas no século XXI, a partir do ano de 2005, logo após a política do governo federal a favor do projeto de uma educação inclusiva. Todavia, a Fenapaes existe há 54 anos, marcada por uma relação de influência política com o Estado (SILVA, 2017, p. 30-31).

\footnotetext{
${ }^{3}$ Utilizamos, neste trabalho, o termo excepcional conforme sua representação difundida pelas Apaes e sua Federação, em que pesem as críticas recebidas por essa designação hodiernamente. Consideramos que, sendo este um trabalho com caráter histórico, devemos retomar a nomenclatura da época, sob o risco de, ao não fazê-lo, incorrermos em anacronismo. Embora, na acepção original, esse termo englobasse não apenas o que hoje se denomina como deficiência intelectual, mas as outras deficiências e até mesmo a superdotação, seu uso pelas Apaes, que, historicamente, direcionaram suas práticas institucionais aos sujeitos "deficientes" e, a fortiori, àqueles com deficiência intelectual, acabou associando a palavra excepcional a essa condição em particular, no plano das representações. Haja vista a polêmica em torno dessa expressão e seu uso em outro tempo histórico que não o atual, colocamo-lo entre aspas nessa primeira ocorrência no corpo do texto. Nos demais casos, porém, para não travar a leitura e já tendo sido expressas tais ressalvas, as aspas são dispensadas. Também para preservar a historicidade, usamos e/ou mantivemos os termos deficiente mental, retardado, entre outras expressões equivalentes.

4 Atualmente, o movimento apaeano adota a sigla Fenapaes para se referir à Federação Nacional das Apaes. Como essa sigla não era usada ainda nas edições pesquisadas de Mensagem da Apae, também não a utilizamos neste texto.

5 Até o começo dos anos 2000, o termo deficiência mental era considerado o mais apropriado e o menos estigmatizante para se referir às pessoas nessa condição. Todavia, desde outubro de 2004, com a realização da Conferência Internacional sobre Deficiência Intelectual, realizada na cidade de Montreal, no Canadá, pela Organização Pan-Americana de Saúde (OPS) e Organização Mundial da Saúde (OMS), passou-se a recomendar o termo deficiência intelectual. Assim, a expressão atualizada deficiência intelectual é equivalente à "deficiência mental" ou, ainda, aos termos mais antigos que já designaram a mesma condição, os quais aparecem, neste texto, por força de remissões históricas, pelas citações das fontes consultadas e/ou nos nomes de instituições mencionadas, tais como: "retardo mental", "retardamento mental", entre outros congêneres.

Educação em Revista|Belo Horizonte|v.36|e222581|2020
} 
Só mais recentemente nota-se o interesse de estudar, na perspectiva da historiografia, essas instituições, suas publicações periódicas, suas práticas e representações culturais (BEZERRA, 2017; BEZERRA; FURTADO, 2017), bem como avançam as investigações sobre suas propostas educacionais, características organizacionais, esferas de atuação e tensionamentos políticos no estabelecimento da relação entre público e privado nas políticas de Educação Especial (JANNUZZI; CAIADO 2013; LEHMKUHL, 2018; RAFANTE; SILVA; CAIADO, 2019; SILVA, 2017). É, pois, no bojo desses estudos mais recentes, que se voltam para a historicidade do trabalho educacional desenvolvido pelas Apaes em sua gênese, que inserimos o presente artigo.

\section{ITINERÁRIOS TEÓRICO-METODOLÓGICOS}

Como forma de investigação e problematização da temática, recorremos, como fonte e objeto de pesquisa, ao impresso periódico Mensagem da Apae em seus primeiros dez anos de existência (1963-1973) ${ }^{6}$. Esse impresso foi eleito por sua pertinência documental para avançarmos na escrita da historiografia da Educação Especial ${ }^{7}$ brasileira, e por sua relevância para a inteligibilidade da configuração desse campo no Brasil, sobretudo no que diz respeito à atuação institucional das Apaes. Vale lembrar que, não por acaso, a primeira Apae surgiu na cidade do Rio de Janeiro, à época Distrito Federal, em dezembro de 1954. A convite do governo federal, para lá se dirigira Helena Antipoff em 1944, já conhecida como educadora de excepcionais, para trabalhar no Departamento Nacional da Criança ${ }^{8}$. Na capital do País, Antipoff impulsionou a fundação da Sociedade Pestalozzi do Brasil, em 1945, iniciando suas atividades com um Círculo de Pais e Educadores (RAFANTE, 2011). Ainda segundo Rafante (2011, p. 172), a educadora "Em 1950, depois de mais 20 anos de intenso trabalho, principalmente com os 'excepcionais', viabilizou uma mobilização nacional em torno desse tema, por meio dos Seminários sobre Infância Excepcional, que ocorreram em 1951, 1952, 1953 e 1955”.

Assim, no Distrito Federal, na década de 1950, havia uma efervescência cultural, com um grande otimismo quanto à educação das massas, à ciência, às medidas de sanitarismo público e à "recuperação educacional" dos excepcionais. Essas movimentações contavam com a presença de organizações movidas, sobretudo, pela iniciativa particular, tais como a Associação Brasileira de Educação (ABE), a Sociedade Brasileira de Higiene (SBH), a Associação Brasileira de Ajuda ao Menor (Abam), clubes de mães para assistência à infância, associações de damas da sociedade, além de missões educativas norte-americanas e dos próprios pestalozzianos, que também ali iam se tornando conhecidos e organizados. Nesse sentido, na então capital da República, já estavam postas a necessidade e as condições básicas para a organização de sociedades específicas de pais de excepcionais, o que se daria com o incentivo e apoio de alguns educadores, intelectuais, médicos e juristas em torno do assunto. Com caráter privado-filantrópico, as Apaes, inspiradas no modelo estadunidense da National Association for Retarded Children (Narc) ${ }^{9}$, logo se expandiram pelo Brasil, atendendo, sob os enfoques clínico-terapêutico,

\footnotetext{
${ }^{6}$ Nas citações diretas extraídas desse periódico e de outras fontes, atualizamos, conforme a necessidade, a acentuação das palavras, de acordo com a norma ortográfica vigente no País.

${ }_{7}^{7}$ É preciso alertar para o fato de que utilizamos o termo Educação Especial quando nos referirmos a essa modalidade educacional em tempos mais recentes e/ou quando fizermos referências genéricas a esse campo de estudos, pois tal designação só aparece oficializada, no Brasil, pela Lei de Diretrizes e Bases da Educação (LDB) 9.394/1996 (BRASIL, 1996). Até então, adotava-se o termo Educação de Excepcionais, nomenclatura que fora empregada pela LDB 4.024/61 (BRASIL, 1961). Desse modo, salvo nos casos indicados anteriormente, a expressão Educaşão de Excepcionais é aqui empregada, porquanto nossas análises se reportam às décadas de 1960 e 1970, quando era essa a designação em voga.

8 O Departamento Nacional da Criança foi criado em 1940, no âmbito do Ministério de Educação e Saúde, ainda na era Vargas, como "o supremo órgão de coordenação de todas as atividades nacionais relativas à proteção à maternidade, à infância e à adolescência” (BRASIL, 1940, n. p.). Reorganizado em 1948, o Departamento foi oficialmente extinto em 1969. Para maiores informações a respeito e sobre o trabalho de Antipoff nesse órgão, consulte-se Rafante (2011).

${ }^{9}$ A Narc surgiu em 1950, nos Estados Unidos da América (EUA). Foi fundada por pais, amigos e familiares de pessoas com deficiência intelectual, a fim de promover e apoiar a educação e a assistência dessas pessoas, que não encontravam suficiente respaldo da ação comunitária e governamental naquele país. Atualmente, é designada como The Arc of the United States (The Arc) (Cf. HISTORY...2016).
} 
pedagógico e assistencial, sobretudo, pessoas com deficiência intelectual e múltipla, de acordo com os termos adotados em suas publicações mais recentes, quanto à caracterização de seu público-alvo. Em 10 de novembro de 1962, na cidade de São Paulo, as Apaes, que não chegavam naquela época a duas dezenas, uniram-se em uma Federação, compondo a Federação Nacional das Apaes, que passou a representá-las oficialmente ${ }^{10}$.

Mensagem da Apae surgiu, pois, justamente nesse e por esse contexto, como um impresso periódico institucional, criado e mantido, de janeiro de 1963 até o presente momento ${ }^{11}$, pela Federação Nacional das Apaes. Desde a origem, o propósito maior dessa publicação foi o de ser um veículo comunicacional publicado para apresentar e representar sua instituição mantenedora, a Federação Nacional das Apaes, constituindo-se como um interlocutor ou mensageiro privilegiado dos apaeanos com a sociedade e deles entre si. Em 1982, ao analisar de forma retrospectiva seu lançamento, o apaeano Justino Alves Pereira, um dos principais colaboradores e editores do impresso nas décadas de 1970 e 1980, enfatizou que a revista fora concebida para ser um veículo de comunicação com tal finalidade (PEREIRA, 1982), pois:

Quando a Federação Nacional das APAEs criou sua revista com um nome tão sugestivo "Mensagem" pensou justamente num meio de levar a cada pessoa que vive em contato com o excepcional a voz desta entidade, a sua realidade, o seu trabalho dignificante. Uma revista que nos unisse mais na causa APAE com o conhecimento da sua "Mensagem". Em levar a cada um de nós um embasamento científico, legislativo e pedagógico relativo ao deficiente. Em publicar discursos e conferências para dar a chance a nossos leitores de estar presente através da leitura, a auditórios e anfiteatros, a toda parte onde for "cantada" a causa do deficiente, defendido [sic] os seus direitos (PEREIRA, 1982, p. 2, grifos nossos).

Nesse sentido, o periódico surgiu com a missão de evidenciar, a todo o País, o trabalho da Federação Nacional das Apaes e de suas filiadas quanto aos excepcionais. O peródico foi direcionado, principalmente, aos próprios associados das Apaes, como forma de promover e ampliar os laços da sociabilidade institucional, já que era preciso dar a conhecer aos apaeanos as orientações emanadas de sua Federação recém-constituída, bem como fomentar a criação de novas Apaes. Vale lembrar que o Brasil era um país no qual a televisão, como veículo comunicacional, estava apenas em seus primeiros passos e longe de se popularizar, bem como os demais meios de comunicação eram escassos, fugazes e dispendiosos, a exemplo da telefonia. O impresso era, portanto, um meio eficaz pela materialidade que emprestava à instituição, enquanto objeto cultural, e pelo conteúdo orientador que transmitia aos associados. Estes, por sua vez, eram pais ou familiares dos excepcionais, além de voluntários que se dispunham a trabalhar em prol desse segmento, podendo ou não serem leigos no assunto. Em virtude de sua temática, o impresso ainda se voltava a profissionais das áreas de saúde, educação e assistência especializadas aos excepcionais, até porque muitos membros das Apaes eram, também, profissionais dessas áreas, e poucas eram as publicações nacionais com esse foco. Logo, o periódico atraiu a atenção de médicos, psicólogos e psiquiatras, normalistas, professores especializados no ensino de excepcionais, assistentes sociais, foniatras, terapeutas ocupacionais, entre outros especialistas atuantes no campo da excepcionalidade $^{12}$. E, nessas contingências, ocupou um espaço lacunar que havia até então no campo das publicações especializadas nesse amplo segmento, em sintonia com as preocupações educacionais, assistenciais, morais e de saúde dos anos de 1960.

10 Em 1962, havia 16 Apaes, tendo 12 delas participado da reunião fundante da Federação Nacional das Apaes (MENSAGEM..., 2014). Atualmente, segundo o site da entidade, existem mais de 2 mil unidades da Apae presentes em todo o território nacional (HISTÓRIA... 2018), o que evidencia a relevância de estudos em torno dessa instituição e sua capilaridade.

11 A última edição da revista, publicada até o fechamento deste texto, foi a de novembro de 2018, ano 51, nº 01, disponível em formato online, no site da Federação Nacional das Apaes. Ressalta-se que a revista, nos tempos atuais, é editada anualmente. 12 Por campo da excepcionalidade, entendemos os saberes multidisciplinares, as práticas, os agentes, as tensões e os conceitos que compunham os domínios técnico-científicos do atendimento especializado aos sujeitos designados como excepcionais, hoje considerados público-alvo da Educação Especial, haja vista as atualizações semânticas e conceituais da área. Para uma reflexão crítica sobre o assunto, leia-se Bueno (2004). 
Desde seu lançamento até o presente momento, em 2019, essa publicação da Federação Nacional das Apaes ostenta uma existência de mais de cinquenta e seis anos, em que pesem algumas interrupções em sua trajetória. Mesmo assumindo características materiais relativamente distintas de seus primórdios, devido a reformulações editoriais e gráficas, Mensagem da Apae tem conservado sua função essencial, na medida em que se define, basicamente, por ser um órgão oficial e porta-voz da Federação Nacional das Apaes. Considerando o período de 1963 a 2016, haja vista que foi nesse último ano que finalizamos a compilação das revistas para nossa pesquisa, foram publicadas 129 edições do periódico. Tal quantitativo tornava complexa a tarefa de operar com todo esse corpus documental, que se revelou heterogêneo em uma análise preliminar. Tornou-se, pois, imprescindível realizar um recorte temporal e serial em relação a todas essas edições, elegendo, ademais, a problemática de estudo para, efetivamente, interrogar esses documentos.

Tendo reunido quase todos os exemplares do periódico ${ }^{13}$, organizamos o inventário da grande coleção das revistas Mensagem da Apae (1963-2016). Analisando essa coleção, folheando as revistas, observando seus conteúdos e formas materiais, percebemos que, em seus primeiros dez anos, as edições de Mensagem da Apae possuíam uma singularidade temática e material que as distinguiam em relação aos rumos tomados por essa revista de $1974 \mathrm{em}$ diante, fato destacado, aliás, pela própria publicação em alguns de seus editoriais. Assim, emergiu o recorte temporal de 1963 a 1973, efetivado a partir das próprias características internas do impresso, que chamamos de sua fase inicial. Deixamos a análise de outras fases para futuros estudos, não sendo possível, aqui, uma delimitação de quantas e como seriam as demais fases já vivenciadas pela publicação.

Operar com essa fase inicial do periódico, além de suas peculiaridades editoriais e gráficas, tornou-se significativo, ainda, por circunstâncias externas às fontes em si mesmas, enquanto objetos materiais, imersos, também, em uma configuração político-social. Afinal, segundo menciona Chartier (1991, p. 180, grifo no original), também é fundamental “[...] traçar, de início, a área social (muitas vezes compósita) em que circulam um corpus de textos, uma classe de impressos, uma produção, ou uma norma cultural". Dessa maneira, o corte temporal definido abrangia um período no qual se destacavam as articulações dos apaeanos antes que se criasse, em 1973, o Centro Nacional de Educação Especial (Cenesp), primeiro órgão do Governo Federal voltado especificamente para essa modalidade educacional em nosso país. Anteriormente à criação desse órgão, o governo federal sequer se incumbira da educação dos excepcionais de forma sistematizada, ficando essa iniciativa, sobretudo, nas mãos de instituições privado-filantrópicas, com destaque para as Sociedades Pestalozzi (RAFANTE, 2011), das quais não nos ocuparemos neste texto, e para as Apaes. Estas, na década considerada (1963-1973), buscavam se fortalecer perante o poder público e a sociedade civil, implementando, como já dito, uma Federação nacional para uni-las e atuar como sua representante; daí o caráter estratégico e calculado do lançamento desse periódico, que nasceu quase simultaneamente à criação da Federação Nacional das Apaes, como seu mensageiro e divulgador precípuo.

Nessa fase inicial de Mensagem da Apae, contabilizamos 19 edições, em um total de 25 números. Tais edições apresentaram diversas características comuns, em que pesem algumas diferenças, a saber: uso exclusivo do preto e branco nas páginas internas, pouco investimento na diagramação e nos recursos gráficos empregados, periodicidade não regular, uso escasso de fotografias ou ilustrações, predomínio da organização do espaço textual em uma só coluna na mancha gráfica, dificuldades em manter uma mesma proposta editorial ao longo desses anos e propagandas somente em alguns números. Foi, portanto, uma fase de experimentações e esforços para garantir a sobrevivência do nascente impresso periódico, que só se consolidaria em meados da década de 1970. O Quadro 1 apresenta, em mais detalhes, os números lançados de 1963 a 1973, tomados como fonte e objeto neste trabalho:

\footnotetext{
${ }^{13} \mathrm{Na}$ tese de doutoramento a partir da qual produzimos este artigo, está explicitado todo o processo de coleta das edições do periódico, o que não é possível aqui detalhar, pelos limites textuais inerentes ao artigo científico (Cf. BEZERRA, 2017). Educação em Revista|Belo Horizonte|v.36|e222581|2020
} 
Quadro 1: Números da primeira fase de Mensagem da Apae (1963-1973)

\begin{tabular}{|l|l|l|l|}
\hline $\begin{array}{c}\text { Ano ou volume de } \\
\text { Mensagem da } \\
\text { Apae }\end{array}$ & \multicolumn{1}{|c|}{ Número(s) } & \multicolumn{1}{c|}{ Período } & Ano de publicação \\
\hline Vol. I & 1 & jan. & 1963 \\
\hline Vol. II & 2 & {$[\text { fev.] }]^{15}$} & 1963 \\
\hline Vol. I & 3 & {$[$ mar.] } & 1963 \\
\hline Vol. I & 4 & {$[$ abr.] } & 1963 \\
\hline Vol. 1 & 5 & [maio] & 1963 \\
\hline Vol. 1 & 6 & [jun.] & 1963 \\
\hline Ano II & 1 & jan.- mar. & 1964 \\
\hline Ano II & 2 & abr.- jun. & 1964 \\
\hline Ano II & 3 & jul. - dez. [set.] & 1964 \\
\hline Ano II & 4 & out. - dez. & 1964 \\
\hline Ano III & 1 a 4 & jan. - dez. & 1965 \\
\hline Ano IV & 1 a 4 & jan. - dez. & 1966 \\
\hline Ano V & 1 & jan. - mar. & 1968 \\
\hline Ano V & 2 & abr. - jun. & 1968 \\
\hline Ano V & 3 & jul. - set. & 1968 \\
\hline Ano V & 4 & out. - dez. & 1968 \\
\hline Ano VI & 5 & out. - dez. & 1969 \\
\hline Não indicado & Não indicado & Não indicado & {$[1972 ?]$} \\
\hline Não indicado & Não indicado & Não indicado & 1973 \\
\hline
\end{tabular}

Fonte: Mensagem da Apae (1963-1973)/Elaboração própria.

Estabelecida essa organização em torno do objeto de pesquisa, relevante para compreender a configuração do campo da excepcionalidade no Brasil, pudemos interrogar essas edições do impresso em sua primeira fase. Consideramos que a década de 1960 e o começo dos anos de 1970 representaram um momento significativo para a história da educação dos excepcionais retardados, com as Apaes e sua Federação dinamizando o campo da excepcionalidade. Foi a partir desse momento que a atenção educacional aos deficientes mentais, em boa parte devido ao trabalho dessas instituições, começou a ganhar maior repercussão, tornando-se um problema na agenda nacional. Assim, partimos da seguinte questão como central para perscrutar as fontes eleitas, a saber: que representações de excepcionais e propostas de sua educação o periódico procurou defender e propagar em sua materialidade e textualidade para orientar as Apaes federadas?

$\mathrm{Na}$ busca por respostas a tal indagação, o impresso foi abordado como fonte e objeto de estudo. Buscamos analisar, de forma articulada, a materialidade e a textualidade inerentes ao periódico, entendendo-o tanto como um dispositivo da memória, preservado no tempo, na acepção de um documento/monumento (LE GOFF, 2013), quanto como suporte mesmo de conteúdos textuais diversos, resultante de escolhas gráficas e mediações editoriais de vários agentes (CHARTIER, 2002, 2007), com determinada performatividade visuoespacial. Compreendemos que um impresso, seja ele qual for, enquanto objeto cultural, institui um espaço físico, uma temporalidade, cadência e códigos próprios de sua decifração, demandando um trabalho historiográfico e arqueológico para que sejam apreendidos os múltiplos sentidos e significados que produz a dinâmica das formas e dos (con)textos. A esse respeito, é mister retomar as considerações de Carvalho (2008, p. 13, grifo da autora), para quem nenhuma revista existe como "[...] veículo neutro para a comunicação dos conteúdos dos textos, mas como

${ }^{14}$ Conforme aparece registrado no periódico.

$15 \mathrm{O}$ uso dos colchetes para demarcar o mês ou ano de publicação é aqui adotado conforme recomenda a Norma Brasileira (NBR) da Associação Brasileira de Normas Técnicas (ABNT) 6023, de 2002. 
performatividade de ordenação da significação deles na materialidade mesma das diversas formas aplicadas à sua edição".

Tal performatividade pode ser entendida, então, como o dinamismo das práticas editoriais, mobilizadas ou ordenadas em função de determinadas representações das quais se investem os editores, promotores e colaboradores de um impresso, como o que ora se destaca. Nesse sentido, é mister considerar, de acordo com o historiador francês, que não pode "[...] haver prática ou estrutura que não seja produzida pelas representações, contraditórias e em confronto, pelas quais os indivíduos e os grupos dão sentido ao mundo que é o deles" (CHARTIER, 1991, p. 177). No bojo dessas reflexões, o autor mencionado ainda pondera que "Sempre a representação das práticas tem razões, códigos, finalidades e destinatários particulares. Identificá-los é uma condição obrigatória para entender as situações ou práticas que são o objeto da representação" (CHARTIER, 2011, p. 16). Logo, esse conceito emerge, simultaneamente, como uma chave de leitura e como guia metodológico na análise historiográfica aqui empreendida, permitindo que a educação dos excepcionais seja captada como objeto de representação dos agentes apaeanos sobre o mundo social que vislumbravam e tensionavam. Consequentemente, conseguimos identificar suas concepções, protocolos de ação, sensibilidades institucionais e interlocutores visados. Eis por que ao se perquirir sobre as representações objetivadas no e pelo impresso, caminhamos, também, rumo à inteligibilidade das práticas

[...] que visam a fazer reconhecer uma identidade social, a exibir uma maneira própria de ser no mundo, a significar simbolicamente um estatuto e uma posição; enfim, as formas institucionalizadas e objetivadas em virtude das quais 'representantes' (instâncias coletivas ou indivíduos singulares) marcam de modo visível e perpétuo a existência do grupo, da comunidade ou da classe (CHARTIER, 1991, p. 183).

Nesses termos, o trabalho com a materialidade do impresso não é, aqui, um exercício diletante ou acessório. Antes, permite-nos apreender em que condições e de que modo Mensagem da Apae pôde se colocar como porta-voz da Federação Nacional das Apaes, representando a perspectiva educacional de trabalho dessa instituição e (con)formando uma identidade apaeana federada a partir dos próprios protocolos de leitura, dos signos visuais e imagéticos e das mensagens veiculadas. Para a perspectiva teórica aqui assumida, as mediações editoriais dizem muito sobre a importância que se atribui ou não a um texto e suas disposições na página impressa, sobre as escolhas gráficas e temáticas, sobre o público-leitor visado e sobre as redes de sociabilidade às quais pertencem os editores, autores e principais destinatários de uma publicação. Foi com base nesse pressuposto que investigamos a forma como era abordada a temática da educação dos excepcionais, pelas Apaes federadas, entre as décadas de 1960 e 1970, buscando realizar um diálogo entre forma e conteúdo. Em virtude disso, citações extraídas do periódico são transcritas ipsis litteris ou mencionadas indiretamente no encadeamento do texto, de modo a compor a narrativa histórica e fornecer um panorama das representações apaeanas, sem travar a leitura. Para que tal escolha metodológica não provoque dúvidas ou ambiguidades quanto à proveniência das informações citadas, inserimos, ao fim do artigo, na lista de referências, uma seção específica que demarca os textos referentes às edições de Mensagem da Apae, distinguindo-os de outros citados no decorrer do trabalho. Feitos esses esclarecimentos, apresentamos, a seguir, os resultados a que chegamos com a pesquisa, inicialmente desenvolvida na forma de tese de doutoramento em educação.

\section{EDUCAR OS EXCEPCIONAIS: A PEDAGOGIA DO AJUSTAMENTO SOCIAL}

A partir desse trabalho investigativo com nosso objeto-fonte, qual seja, o impresso Mensagem da Apae, foi possível depreender que, nos momentos iniciais de sua emergência institucional, as Apaes foram constituindo uma prática educacional que levava em conta um amplo e nem sempre sistemático programa educativo, articulado com as demandas contextuais que lhes eram postas e com as representações que precisaram promover para sua própria sobrevivência institucional. Essa prática tinha por base uma pedagogia empírica, impregnada dos saberes e fazeres clínico-terapêuticos das equipes multidisciplinares formadas para enfrentar o chamado problema do excepcional, mais focada na (re)habilitação social do deficiente e em seu "tratamento" do que na sua escolarização. Nesse sentido, apelava-se para os saberes 
e fazeres de diversos profissionais, reconhecendo-se, secundariamente, o papel do professor, comum ou especializado, e da própria escola. Tanto que, para os apaeanos, cabia aos

[...] poderes públicos facilitar a constituição de equipe de técnicos encarregados da educação especial, porque o excepcional necessita não só do professor especializado, mas também dos cuidados do médico, do psicólogo, do orientador vocacional, do terapeuta ocupacional, do fisioterapeuta, do foniatra e outros, conforme a natureza das deficiências verificadas no caso concreto. Da equipe participa também o professor não especializado quando se consegue integrar o excepcional nas classes comuns (NOTICIÁRIO, 1965, p. 38, grifos nossos).

Por isso, ao menos no período aqui considerado, de 1963 a 1973, pode-se dizer que prevaleceu uma Pedagogia do Ajustamento Social, cuja meta era normalizar ou moldar o "retardado" para torná-lo mais aceito no convívio social, "[...] mirorando o desajuste individual dos deficientes mentais [...]” (BORRAIZ, 1964, p. 43), “[...] através do desenvolvimento da normalização de sua personalidade total, da readaptação e da reinserção no meio social" (CAETANO, 1966, p. 20). Essa perspectiva era justificada por uma representação da realidade pela via do tecnicismo, o qual, embora viesse sendo difundido no Brasil desde os anos de 1950, associado à ideia de mordenização nacional, ao desenvolvimentismo econômico e à Teoria do Capital Humano, tornou-se dominante no País com o golpe civil-militar de 1964 (Cf. FERREIRA JÚNIOR; BITTAR, 2008; GATTI JÚNIOR, 2010). A figura dos especialistas "neutros", com seu conhecimento "técnico-científico" e seus planejamentos eficazes, era a grande aposta para a solução dos problemas brasileiros, inclusive o dos excepcionais, perspectiva que não deixou de ser incorporada, também, pelos apaeanos e, consequentemente, reproduzida, instigada e valorizada no impresso Mensagem da Apae. Era um tempo de otimismo em torno da ciência, da tecnologia e da técnica, vistas como potências capazes de transformar o mundo e, nesse sentido, de transformar, controlar e desenvolver o próprio homem, ajustando-o aos padrões comportamentais de eficiência e produtividade requeridos pelo contexto.

No bojo dessas representações coletivas, era anunciado que, para se equiparar às nações "desenvolvidas", o Brasil precisava o quanto antes definir "[...] uma linha de combate à deficiência mental [...]" (SUBSÍDIOS..., 1973), essa "[...] moléstia que invalida[va] 3\% da população desde a mais tenra infância [...]” (KRYNSKI, 1963, p. 4), de forma a higienizar intelectualmente a população brasileira, afastá-la das limitações cognitivas e recuperá-la, quando ainda fosse possível, sob "[...] as normas de cultura dos países civilizados e desenvolvidos" (KRYNSKI, 1964, p. 16). Como o governo - em suas instâncias federal, estadual e municipal - alegava não poder educar satisfaforiamente os retardados, pois sequer conseguira expandir a educação elementar para todos os brasileiros, com o agravante de que nem existiam "[...] professores primários em número suficiente para atender à população normal" (SUBSÍDIOS..., 1973, p. 97), os cidadãos de boa vontade deveriam assumir essa tarefa patriótica, colocando suas aptidões, conhecimentos e recursos a serviço da Nação. Considerava-se que "O ônus social que representa[va] um deficiente mental é muito grande; sua assistência é obrigação da coletividade" (KRYNSKI, 1964, p. 18). Assim, combatia-se o "grande mal" que assolava, sobretudo, as classes mais pobres, necessitadas de intervenção clínico-terapêutica para não se tornarem elementos de distúrbio social. No dizer de Borraiz (1964, p. 43, grifos nossos),

\footnotetext{
Todos nós, conscientes do problema, devemos empreender os nossos esforços a fim de que os pobres também possam colher os modernos benefícios terapêuticos ou clínicos, para que, pelo menos, não se estendam as consequências do mal, quando evitáveis.

$\mathrm{Na}$ dedicada contribuição de todos os cidadãos conscientes, em prol dos excepcionais, desejamos alcançar aquela ação pública à qual deve somar-se, mais decididamente os objetivos comuns, possibilitando o convívio social, ou minorando o desajuste individual dos deficientes mentais e que serão adultos amanhã, capaz̧es de também prestar serviços à coletividade, passando de ônus a seres úteis. Há portanto, vasta obra a ser realizada e que se consubstancia, principalmente, na compreensão.
}

Tal ideologia, que já era disseminada com notável repercussão a partir dos anos de 1960, ganhou ainda mais notoriedade com a emergência da ditadura civil-militar (1964-1985). Esta ampliou o 
poderio da iniciativa privada, defendendo que os brasileiros precisavam ser úteis e produtivos ao País, em vez de se envolverem em conflitos e reivindicações sociais que atrapalhassem o progresso ordeiro. As Apaes, então, beneficiaram-se dessas circunstâncias, reforçando, como estratégia, posicionamento semelhante, o que não só era coerente com suas origens e filosofia institucional, como também evitava que fossem comprometidos ou ameaçados os seus interesses "Numa época em que os partidos políticos de esquerda estavam proscritos, os sindicatos estavam sofrendo uma forte intervenção estatal e os movimentos sociais, como um todo, eram vigiados e controlados pelos órgãos de repressão" (PRIORI et al., 2012, p. 11). Dito de outro modo, criavam-se condições em que cada um ocupava um espaço na sociedade, tal qual a representação da sociedade técnica imperante, para manter o equilíbrio e suposta harmonia do tecido social. Ao excepcional, cabia, pois, um lugar determinado, isto é, o de não perturbar o progresso que se anunciava, com aparência de ser também um cidadão produtivo.

A esse respeito, cumpre relembrar que "promover medidas de âmbito nacional que visem a assegurar o ajustamento e o bem-estar dos excepcionais, onde quer que se encontrem" (OBJETIVOS..., 1964, p. 4) era um dos objetivos da nascente Federação das Apaes, privilegiando-se, portanto, uma abordagem de educação social, não formal e assistencial, chamada, pelos apaeanos, de educaşão integral (A APAE..., 1968; II CONGRESSO..., 1965). Propositadamente, destacamos os adjetivos qualificadores da abordagem educacional apaeana justamente porque carecem de explicações e esclarecimentos que lhes deem sentido naquele tempo, os quais, doravante, passamos a evidenciar. Ora, desde o fim da década de 1950, o Brasil era cada vez mais representado e imaginado como uma nação predestinada a ser desenvolvida, a se transformar em uma liderança mundial. Ufanista, era o "[...] gigante adormecido, que finalmente despertava e buscava o lugar que merecia no concerto das nações" (PALACIOS, 2008, p. 351, grifos do autor); era o país do futuro, futuro esse que "[...] faria do Brasil a locomotiva do mundo" (SILVA, 1996, p. 14). Os nacional-desenvolvimentistas (1946-1964) haviam incentivado essa utopia quanto ao desenvolvimento econômico brasileiro, corroborada, em seguida, pela ditadura civil-militar (1964-1985), com o discurso de nação-potência, em que pesem as diferenças políticas, econômicas e ideológicas do modelo desenvolvimentista adotado por um e outro governos. Para colocar o País nos trilhos do progresso e fazer funcionar essa locomotiva, um ingrediente era visto como fundamental: a educação, que tornaria o povo apto a ingressar nos novos hábitos de consumo e trabalho, em uma sociedade que se industrializava e se urbanizava em ritmo acelerado. Panaceia de todos os males sociais, com o advento dos governos civil-militares, a partir de 1964, essa educação assumiu características tecnicistas e despolitizadas, mas, ainda assim, não deixou de ser o grande triunfo para o rápido crescimento econômico do País, na concepção da época (Cf. FERREIRA JÚNIOR; BITTARA, 2008; GATTI JÚNIOR, 2010).

Promover a educação - aqui concebida não apenas em seu formato escolar, mas também como projeto social - era entendido como o caminho para a saída do subdesenvolvimento a que o Brasil estivera relegado, de modo que todos os brasileiros precisavam dela para tomar parte na grande tarefa de (re)construção nacional, rumo ao status de país de Primeiro Mundo. Por isso mesmo, naquele cenário, a educação visada não era para ruptura da ordem estabelecida, mas deveria ajustar os indivíduos ao modelo desenvolvimentista adotado, assegurando que, mesmo na sociedade em constante transformação, estes pudessem continuar disciplinados, eficientes e ordeiros, capazes de agir racional, técnica e pragmaticamente para o bem de seu país. O lema do momento era "Amoldar-se, ajustar-se ou perecer eis o problema” (KRYNSKI, 1964, p. 12). Adaptação, sem revolta ou desequilíbrio, às condições de vida tão incertas, aceleradas e mutáveis era a palavra-chave. Perante tais circunstâncias, o inadaptado seria, portanto, um estorvo que colocava em risco todo o bom funcionamento da engrenagem social e os propósitos encomiásticos de projeção nacional, demandando, portanto, recuperação e ajuste de sua conduta por meios técnicos e morais. Ora, adaptação e ajustamento eram ainda mais problemáticos no caso dos excepcionais retardados, que, sendo numericamente expressivos, precisavam, também, "[...] voltar ao convívio social, como parcelas úteis ao engrandecimento do Brasil” (ROCHA LAGOA, 1973, p. 37). Do contrário, tornar-se-iam uma ameaça à higidez social e aos planos de progresso da naçãopotência que se queria fazer do País. Sem respaldo educativo, apregoava-se, então, que o excepcional seria um elemento de perturbação e de "retardo" do progresso nacional, uma verdadeira fonte de infecção ou calamidade social, sendo que "[...] a resultante é o homem desajustado, incapaz de se ajustar 
convenientemente à sociedade e consequentemente, incapaz de melhorar os padrões futuros desta sociedade" (KRYNSKI, 1964, p. 13).

Por outro lado, se a escola pública republicana já era representada como elemento de redenção e de desenvolvimento nacionais, nem todos, porém, "cabiam" nela. Punha-se, então, a necessidade de se pensar em um espaço para esses sujeitos, isto é, tanto para aqueles que começavam a ser produzidos como um resíduo indesejável dessa escola, como para aqueles que viviam segregados, em condições insalubres, em instituições asilares, ou confinados a seus lares, impedindo a "produtividade" econômica dos pais e familiares, que se viam ocupados com o excepcional. Por isso, a relevância de educação desse indivíduo precisava ser difundida a toda a sociedade, com apoio da imprensa, principalmente escrita e falada, e das diveras organizações sociais existentes, além do poder público. Tratava-se, pois, de, literalmente, “[...] instalar uma mentalidade favorável para o problema do excepcional" (SCHILLING, 1969, p. 33). Para tanto, a orientação apaeana era que "Deverão ser usados todos os meios e métodos de divulgação, inclusive este que consideramos básico: inclua no seu vocabulário e na sua conversação diária alguma coisa a respeito da APAE e seus propósitos" (SCHILLING, 1969, p. 33). Desse modo, em sua abordagem pedagógica, os apaeanos entendiam que, para viabilizar a educação dos excepcionais deficientes mentais, era fundamental, também, educar os pais e a sociedade para que pudessem desempenhar o papel de agentes educativos desses sujeitos. Eis o que era entendido como o trabalho de educação social empreendido pelas Apaes. Assim, poder-se-ia ampliar o trabalho pedagógico-terapêutico realizado nas instituições especializadas e continuá-lo no lar, na comunidade e no trabalho que, porventura, o excepcional viesse a ter.

Logo, a educação não tinha, entre os apaeanos, um foco precípuo nas práticas escolares ou curriculares formais, porque não era esse, de fato, o sentido que atribuíam ao trabalho educativo. Por isso, chamamos de educação paraoficial a essa abordagem pedagógica conduzida pelas Apaes federadas, em seus estabelecimentos educacionais ou naqueles sob sua manutenção. Isso porque, embora de modo incipiente, governos estaduais e municipais já vinham realizando, também, a abertura, no contexto do sistema público e oficial de ensino, de classes especiais em caráter formal, anexas às escolas primárias e aos Grupos Escolares. Tal informação apareceu, inclusive, noticiada pelas páginas de Mensagem da Apae (ALVES, 1964; APAE DO RECIFE, 1963; FLORENZANO, [1972?]; NOTÍCIA, 1963). Além disso, existiam classes do gênero em instituições da rede privada de ensino comum ${ }^{16}$. Nessas classes, eram, geralmente, recebidos os alunos educáveis, cabendo às Apaes os casos mais "comprometidos" (Cf. DRUMOND, 2015; KASSAR, 1999). Tal classificação, vale dizer, obedecia às possibilidades educativas e adaptativas do indivíduo, tendo por base os resultados de "[...] provas psicológicas, especialmente criadas para este grupo de crianças [excepcionais]" (PEREZ-RAMOS, 1966, p. 16).

Ora, configurando-se esse cenário, não foi mera casualidade Mensagem da Apae ter publicado a definição "exata" de cada categoria de "retardo mental", conforme o jargão da época. E muito menos foi simples coincidência os editores do periódico terem se preocupado com isso justamente no fecho do mesmo número em que, na página antecedente, no anverso da folha, era veiculada a campanha estadual, em prol das crianças excepcionais, no começo do ano letivo de 1964, pelo então Serviço de Instituições Auxiliares da Escola, do Departamento de Educação do estado de São Paulo (Cf. Figura 1). Assim, a Federação Nacional das Apaes manifestava o intuito de demarcar seu lugar de atuação no campo da excepcionalidade, recorrendo à ordenação performática da significação desse conteúdo na materialidade das estratégias aplicadas à edição do citado número (Cf. CARVALHO, 2008). Criava-se, pois, uma chave de leitura que induzia o leitor a concluir, per se, sobre a imprescindibilidade do trabalho das Apaes, sobretudo para os excepcionais que "[...] não possam ser devidamente atendidos pelas próprias escolas" (NOTICIÁRIO, 1964, p. 29), resguardando-se para as instituições especializadas apaeanas o filão dos treináveis e, por vezes, dos dependentes, conforme as definições que apareciam imediatamente na página seguinte, indicadas no verso da folha, nesta disposição:

\footnotetext{
${ }^{16}$ Embora retratando o período entre as décadas de 1970 a 1990, a tese de Dallabrida (2006) traz importantes considerações a respeito.
} 
Figura 1 - Divulgação, no noticiário, de campanha estadual paulista pró alunos excepcionais, seguida de esclarecimento sobre as "categorias" do retardo mental segundo seu nível de "educabilidade" (anverso e verso).

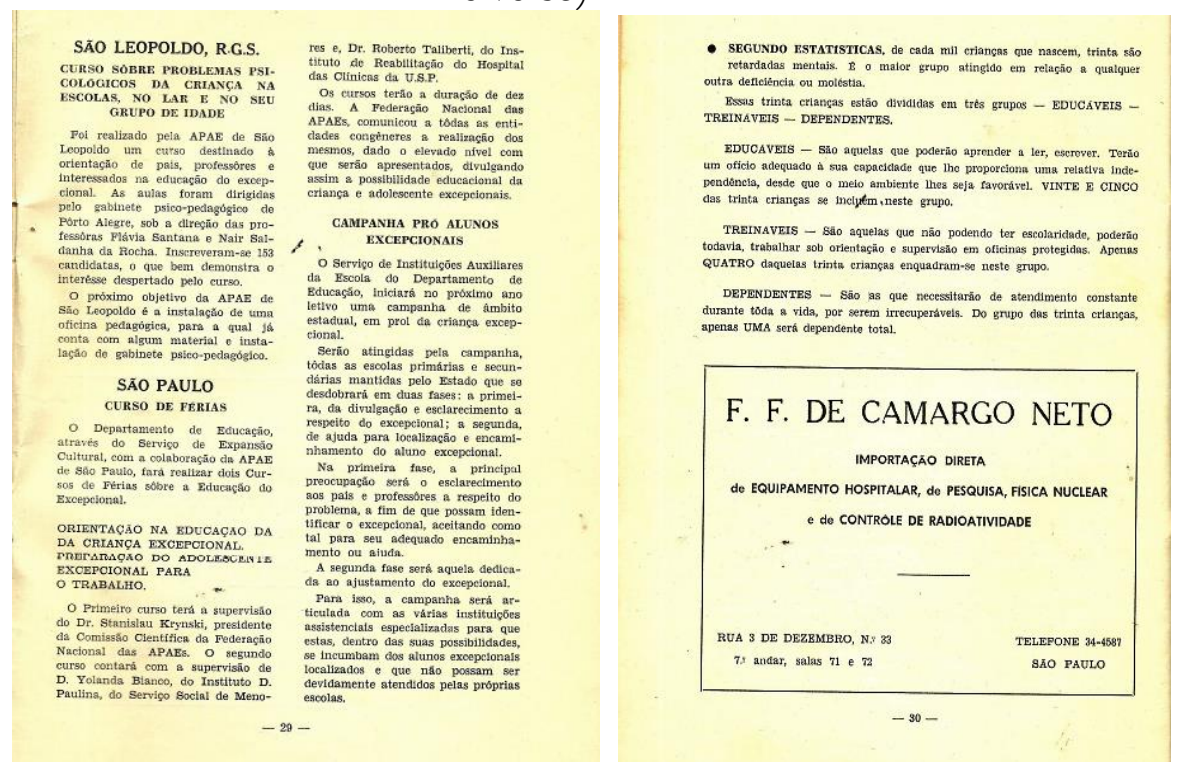

Fonte: Mensagem da Apae (ano II, n. 1, p. 29-30, jan. - mar. 1964).

Esse foco nos treináveis ajuda a entender o porquê de, naquele momento, o atendimento das Apaes aos excepcionais não ter como prioridade o ensino da leitura, da escrita ou da aritmética, como se dizia, distanciando-se da proposta escolar (Cf. PEREZ-RAMOS, 1966), a qual seria mais viável aos educáveis, que poderiam frequentar até mesmo classes especiais em escolas públicas. Declaradamente, a premissa educacional apaeana era, portanto, de que “[...] a alfabetização não é nosso objetivo maior, mais valendo aprender [o excepcional] uma atividade profissional que ler sem o devido entendimento etc.” (SEIXAS, 1969, p. 148). Nesse sentido, para os apaeanos, a prática pedagógica não era desinteressada, mas deveria ser utilitarista e instrumentalizante para "[...] proporcionar aos deficientes esta educação tão necessária à sua integração na sociedade” (BORRAIZ, 1964, p. 44), privilegiando-se o treino de habilidades elementares na instrução dos aprendizes deficientes mentais; daí o nome treináveis. Tais habilidades dificilmente poderiam lhes dar uma integração social tão promissora, como o discurso instituído fazia crer, uma vez que a cultura letrada se impunha, e as exigências laborais se tornavam cada vez mais complexas e aceleradas, com o propalado desenvolvimento econômico do País. Ainda assim, visava-se garantir, nas instituições, escolas e centros especializados criados pelas nascentes associações da Federação Nacional das Apaes, geralmente em regime de externato ou de semiexternato, que esses indivíduos, principalmente os treináveis, pudessem desenvolver habilidades sociais básicas e, se possível, encontrar uma ocupação laboral para liberar a família e a sociedade do ônus que representavam (BORRAIZ, 1964; SUBSÍDIOS..., 1973; FLORENZANO, [1972?], GONCCALVES, 1964, 1968a,b; KRYNSKI, 1964; PEREIRA, 1964). Com base no lema apaeano de "mais amor e compreensão", conjugado à representação do deficente como uma flor carente de amparo para "desabrochar" e crescer, ideia a que nos remete a imagem-símbolo adotada pela Federação Nacional das Apaes desde sua fundação (Figura 2), era mister:

[...] proporcionar [aos deficientes mentais] condições favoráveis, intrínseca e extrinsecamente, para o desabrochamento e o amadurecimento integral do homem em formação, embora seja ele carente em necessidades fundamentais que repercutem em si e no meio ambiente, provocando conflitos que devem ser reduzidos e tratados (CAETANO, 1966, p. 22, grifos nossos). 
Figura 2 - Quarta capa de Mensagem da Apae em 1968.

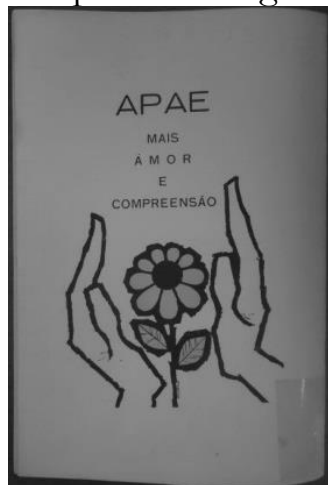

Fonte: Mensagem da Apae (ano V, n. 2, abr. - jun. 1968).

Nesse empreendimento, diversas técnicas e terapias eram mobilizadas para realizar " [...] a orientação pedagógica, a terapêutica ocupacional - as diversas etapas por que passa o indivíduo excepcional deficiente mental até atingir razoável adaptação à sociedade" (XAVIER, 1963, p. 2). Para tanto, grande ênfase era dada aos materiais e métodos da chamada "educação ativa" e funcionalista, isto é, uma (re)leitura apaeana das metodologias escolanovistas, considerando que "[...] os recursos pedagógicos que estimulam as funções de adaptação ao ambiente familiar, à vida social e ao trabalho profissional, bem como a formação moral é o que permitirão uma vida regular ao deficiente mental que se torna adulto" (CAETANO, 1966, p. 21, grifos nossos). Ainda em relação a tal abordagem metodológica, defendida como a mais adequada para esse público, era ressaltada

[...] a importância dos jogos educativos, que despertam a atenção e o exercício dos sentidos; das liçoes de coisas, que põem as crianças em contato direto com as realidades concretas; da cerâmica, do desenho, da música, como modos de expressão; da ginástica, da rítmica e da reeducaşão psico-motora, para suprir os deficits motores quase sempre associados à deficiência mental; do trabalho manual [...]; das atividades sociais e da religião, que dão a justa medida das relações com os semelhantes e com Deus, e permitem a compreensão da vida temporal e espiritual, dentro do possível (CAETANO, 1966, p. 22, grifos nossos).

Isso não significava que as Apaes federadas não dessem, naquele momento, alguma importância à educação formal, mas os agentes dessas entidades representavam-na como parte de uma rede de práticas que compreendia o processo geral de (re)habilitação, condicionamento e treino do excepcional (PEREZ-RAMOS, 1966), bem como formação dos "bons hábitos" (CAETANO, 1966) para "[...] minorar os efeitos do mal [...]" (BORRAIZ, 1964, p. 43). A precisão técnica, desejada em níveis "cirúrgicos" - embora nem sempre assim concretizada - era a grande aposta da abordagem educativa então praticada, visto que "Uma educação apropriada pode[ria] diminuir, sensivelmente, o deficit" (CAETANO, 1966, p. 21), impingindo ao trabalho pedagógico um apelo quantitativo, que permitisse o aproveitamento mais eficaz e gradativo das capacidades do deficiente. Desse prisma, os saberes acadêmico-escolares até poderiam ser ensinados, desde que incorporados e subordinados à prática de uma terapêutica educacional, a qual dava a última palavra. Aliás, conforme se pensava,

A deficiência mental, de um modo geral, gera uma inadaptação acompanhada, o mais das vezes, de distúrbios do comportamento. Se assim é não vemos possibilidades de aproveitamento real e eficiente da capacidade ainda existente, se a criança não for [...] primeiramente considerada em sua integridade, como pessoa em formação e carente de um tratamento que envolva sua personalidade total. [...]. A educação e a reeducação do deficiente mental atendem a situações e necessidades fundamentais. As práticas e técnicas por elas empregadas, antes de serem práticas e técnicas meramente escolares são antes e acima de tudo, práticas e técnicas terapêuticas, necessitando de controle, de orientação e até mesmo de execução por um técnico, altamente experimentado, como deve ser o Psicólogo (CAETANO, 1966, p. 22, grifos nossos).

Assim sendo, no "tratamento psicopedagógico" da deficiência mental, considerava-se que "O predominio das preocupações de ensino, que às vezes dominam os métodos das classes de deficientes [...] é 
fruto de um preconceito escolar perigoso para qualquer tipo de criança, mormente para o deficiente mental" (CAETANO, 1966, p. 21, grifoss nossos), devendo-se, ainda, "[...] evitar o cansaço provocado por um programa demais ambicioso" (CAETANO, 1966, p. 21, grifos nossos). Como visto, importava mais a educação dos sentidos que a educação intelectual, posto que "A mera educação [formal] do atrasado mental criança não basta. É preciso garantir-lhe a adaptação social num momento em que as condições culturais constituem obstáculo sério à eficiência de viver do atrasado" (COMO SURGE..., 1963, p. 10, grifos nossos). É significativa, nesse caso, a marca tipográfica do hífen, que liga o termo atrasado mental à palavra criança, revelando que, no plano das representações, o deficiente mental era equiparado a uma criança "pré-escolar" - portanto, infantilizado e carente de adaptação ao mundo. De sua vez, a figura da criança, por ser ainda vista, naquele contexto, como um ser frágil, inabilitado, dependente e heterônomo, coadunava-se perfeitamente com a imagem do excepcional, representando-o, simbolicamente, com o empréstimo de suas propriedades.

Logo, o ensino sistematizado era, por assim dizer, repelido, ou pelo menos preterido, em nome de uma orientação pedagógica pragmática, utilitarista, voltada para o treino adaptativo e aprendizagem vocacional dos excepcionais. Em síntese, na representação dos apaeanos, isto era o que entendiam por uma educação integral, como evidencia este outro excerto:

Considerar a reabilitação como aspecto isolado ou prolongamento da educação é um erro que se tem cometido frequentemente na assistência ao deficiente mental.

A educação, tomada no seu sentido estrito de assimilação dos mecanismos de alfabetização e aprendizagem de conhecimentos mecânicos é, na realidade, um aspecto da reabilitação.

Uma das metas fundamentais a serem atingidas com a assistência ao deficiente mental é o ajustamento ocupacional. Sem isto, a educação torna-se sem sentido. Alfabetizar um deficiente mental e devolvê-lo somente com esta noção ao seio de sua família e comunidade, é malbaratar dinheiro, uma vez que depois de certo tempo de inação e falta de exercício, os conhecimentos acadêmicos, duramente adquiridos durante 4 ou 8 anos de escolaridade, perdem-se totalmente. O ajustamento ocupacional não é simplesmente 'arranjar um emprego' como antes se pensava, pois, se para isso fosse necessário que o indivíduo tivesse uma apresentação razoável, o deficiente mental que não soubesse amarrar seus sapatos ou dar um nó na gravata não estaria bem preparado. Assim, o indivíduo deverá ser preparado ocupacionalmente, durante o processo educacional de tal maneira que adquira dentro de suas possibilidades, as atitudes, os hábitos e as habilidades necessárias para enfrentar uma situação de vida real na comunidade social e de trabalho a que vai pertencer. Isto é o que se deve entender por reabilitação (FLORENZANO, [1972?], p. 23-24, grifos da autora).

Conseguintemente, não se encontra em Mensagem da Apae, no período abrangido por esta pesquisa, um "programa escolar" para o deficiente mental, mas indicações de como "recuperá-lo" e ocupá-lo, indicando que esse sujeito era ainda representado como um "inválido" social, um "[...] aleijado do cérebro" (RABELO, 1964, p. 47), um ser não produtivo e dispendioso, que precisava, urgentemente, da reabilitação para ser transformado em um indivíduo apto e menos oneroso para a sociedade, por meio de uma "Educação Emendativa" (PEREIRA, 1964). Nesse sentido, tornar o deficiente mental um sujeito educado e ajustado ao meio social significava, portanto, capacitá-lo a "[...] executar as atividades práticas necessárias para isso e, se possível, preparando-o para uma tarefa profissional" (SUBSÍDIOS..., 1973, p. 81), da seguinte maneira:

A criança usa muito as mãos? É preciso arranjar-lhe serviço de sapateiro, por exemplo. Com o lucro do seu trabalho, toma uma personalidade mais desenvolvida.

Observar o excepcional, aproveitar as suas tendências positivas, eis as necessidades.

José tem 23 anos de idade mas idade mental de 4. Gosta de serrar? Vamos aproveitá-lo, encaminhandoo para marcineiro. Maria gosta de lidar com fios. Fará cestas de macramé, etc. e ganhará dinheiro com esse trabalho e terá uma atividade útil à sociedade (COMO SURGE..., 1963, p. 10-11, grifos nossos).

Como se pode depreender, desde o início do processo educacional-emendativo, a meta era preparar o deficiente para alguma atividade ocupacional, de simples execução, recorrendo-se ao treinamento precoce e a técnicas pedagógicas que potencializassem a reabilitação vocacional entre os retardados mentais (PEREIRA, [1972?]). Essa orientação "pedagógica" vinha acompanhando as Apaes 
desde sua fundação, no Rio de Janeiro, em 1954. Aliás, o número 3 de Mensagem da Apae, publicado no ano de 1968, abordara, justamente, o trabalho educacional desenvolvido pela associação carioca, a primeira das Apaes, tomada, à época, como referência para as demais. Por isso, torna-se um parâmetro para demonstrar, de forma ainda mais clarividente, como era abordada, nessas instituições, a educação dos excepcionais. Na Apae Rio, funcionava a Escola Primária Experimental Professor La-Fayette Cortes, "[...] o mais antigo dos nossos estabelecimentos para a recuperação do deficiente mental: nasceu em 1955, com apenas 21 crianças procedentes das classes especiais das escolas primárias do Estado [do Rio de Janeiro/Guanabara]" (A APAE..., 1968, p. 6, grifos nossos). Segundo o periódico apaeano, a escola tinha por finalidade "[...] propiciar a educação integral da criança excepcional visando a sua integração social [...]" (A APAE..., 1968, p. 6). Essa educação, adjetivada de integral, reforçava, todavia, uma prática pedagógica mecanicista, voltada para o treino de habilidades manuais e perceptivo-motoras, além de destacar a formação de hábitos higiênicos e laborais. Na proposta da escola, seguida por tantas outras do gênero, nas décadas de 1950 a 1970, a escolaridade (ler, escrever e contar) figurava como apenas uma dessas práticas, que, muito sugestivamente, aparecia como o penúltimo item de todo o programa educativo, como se pode conferir nesta figura, extraída de Mensagem da Apae:

Figura 3 - Programa educativo e organização pedagógica da Escola Primária Experimental Professor La-Fayette Cortes, da Apae carioca.

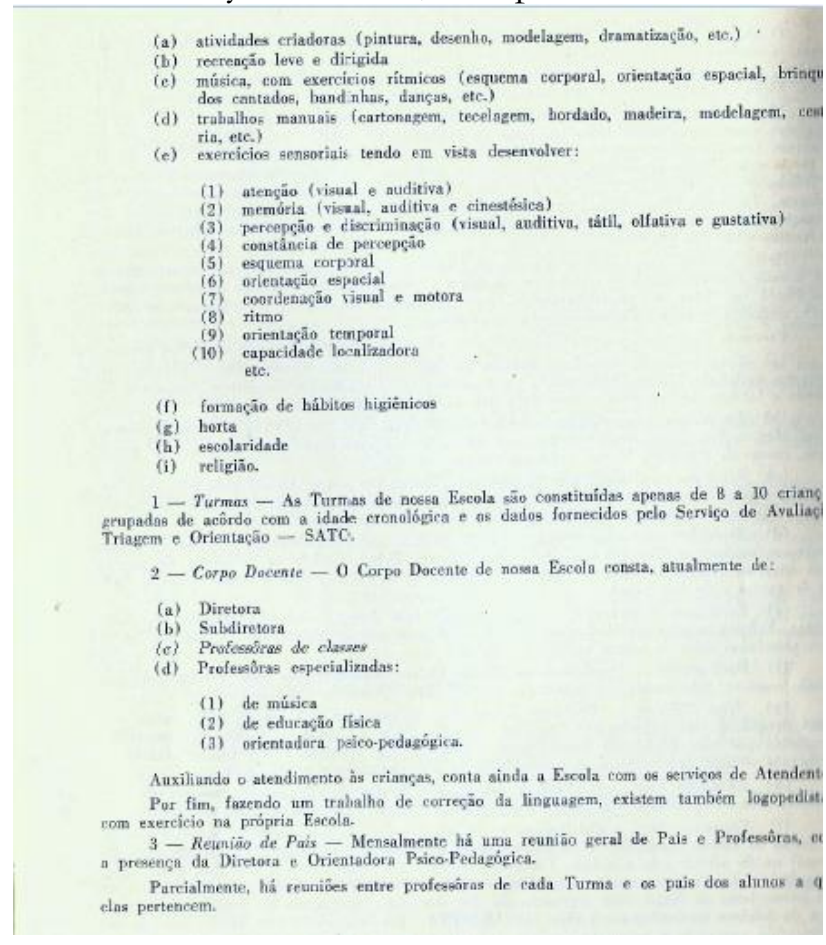

Fonte: Mensagem da Apae (ano V, n. 3, p.7, jul. - set. 1968).

$\mathrm{Na}$ mesma direção, práticas muito semelhantes eram noticiadas, pelo impresso, no sul do País, na Escola Especial Municipal "Recanto do Amor e Compreensão", inaugurada em junho de 1964, na cidade de Novo Hamburgo-RS, “[...] graças ao esforço comunitário, Prefeitura Municipal e Associação de Pais e Amigos dos Excepcionais [...]" (BERCHT, 1966, p. 28). A Apae, nesse caso, era colaboradora e uma das mantenedoras do empreendimento, que contava também com o apoio do governo municipal. Como se divulgou em Mensagem da Apae, as atividades desenvolvidas na citada escola seriam estas: "Linguagem - Aritmética - Atividades da Vida Diária - Desenvolvimento da linguagem (dificuldades na fala) - Estímulos Sensoriais - Desenho - Estória dirigida - Educação Física - Música [...]” (BERCHT, 1966, p. 29). E, como era característico nesse enfoque pedagógico, trabalhavam-se "[...] atividades sociais e recreativas como passeios, piqueniques, visitas, festas por eles preparadas [alunos e professoras]" (BERCHT, 1966, p. 29). Outrossim, recebiam "As crianças diariamente [...] merenda escolar e maior 
atendimento à higiene, devido às condições precaríssimas de bigiene e alimentação em seus lares" (BERCHT, 1966, p. 29, grifos nossos). Além do que já foi exposto, essas práticas revelam, ainda mais incisivamente, a premissa assistencial que estava impregnada ao trabalho educativo ofertado pelas instituições apaeanas.

À vista disso, as Apaes pautavam-se na concepção de que os retardados mentais precisavam aprenderpara trabalhar e trabalharpara serem integrados pela sociedade, quando então poderiam dela participar como um membro "recuperado", finalmente habilitado como ser social. Era uma lógica funcionalista. Nesse processo, caberia às associações apaeanas "[...] ajudá-los a atingir o máximo, o seu potencial para o trabalho, o emprego" (PEREIRA, [1972?], p. 31). Dito de outro modo, os apaeanos eram defensores da tese de que "[...] uma vez que [os excepcionais] não se alfabetizem, aprendem, no entanto, uma profissão útil [...]" (COMO SURGE..., 1963, p. 10). Essa tese foi até mesmo manipulada no processo de produção material de Mensagem da Apae, pois os editores quiseram, em algumas circunstâncias, induzir o leitor a defendê-la, propositadamente levando-o a confrontar as realidades estadunidense e brasileira quanto à empregabilidade dos deficientes mentais. Isso ocorreu, por exemplo, na última edição de 1968, que apresentava o texto $O$ Excepcional e o Trabalho, explanando sobre a legislação trabalhista no Brasil e as necessidades de sua adaptação para atender aos excepcionais, solicitando, inclusive, a dispensa da prova de alfabetização, exigida, à época, aos menores de idade para que fosse expedida sua carteira de trabalho (GONÇALVES, 1968b).

Segundo veiculou o impresso apaeano, “[...] essa exigência poderia ser dispensada quando devidamente comprovado que o desenvolvimento intelectual do menor, dada a deficiência mental, o impede de aprender a ler, escrever e contar, mesmo depois de aplicados os processos de educação especial" (GONÇALVES, 1968b, p. 10). Dessa forma, abria-se caminho para a imediata profissionalização do deficiente, a fim de que fosse um trabalhador produtivo, pois, "[...] como aconteceu em outros países [...], a admissão de excepcionais em funções adequadas é economicamente vantojosa [...]" (GONÇALVES, 1968b, p. 12, grifos nossos). Logo mais adiante, ainda na citada edição, os editores de Mensagem da Apae demonstravam essas vantagens, já comprovadas "numericamente" nos Estados Unidos, mediante a publicação de um excerto, proveniente daquele país, no qual se comparava, de maneira lacônica, a atuação profissional de "retardados" e de "normais" em serviços de restaurante (Figura 4). Com tal expediente, instigava-se o leitor a concluir pela validade da tese apaeana ou, pelo menos, a intuí-la em uma leitura não muito sistemática do impresso, pois, sendo um texto simplificado, bastante conciso e com título chamativo, dificilmente o leitor ficaria indiferente a seu conteúdo, apreendido já em uma rápida "olhadela", o que tornava eficiente a circulação da mensagem apaeana.

Figura 4 - Comparação entre a atuação profissional de trabalhadores "retardados" e "normais" em serviços de um restaurante, a partir de dados estadunidenses, traduzidos no periódico.

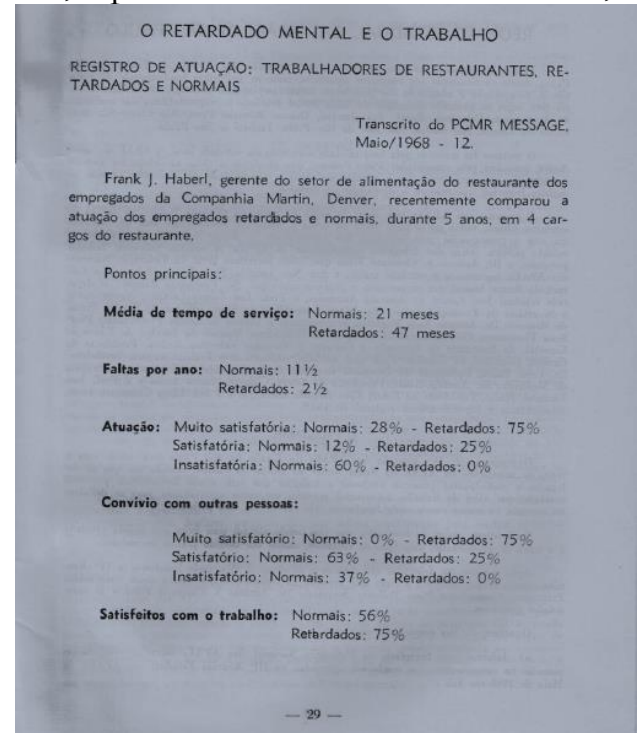

Fonte: Mensagem da Apae (ano V, n. 4, p. 29, out. - dez. 1968). 
Em 1963, recurso similar também foi empregado no número 6 de Mensagem da Apae, quando se forjou um protocolo de leitura pelo qual o leitor era levado a pensar que a educação das crianças excepcionais deveria ser sempre balizada pela necessidade de sua ocupação laboral, esta caracterizada como um bom negócio. Na materialidade do impresso, duas matérias eram apresentadas lado a lado, impactando a recepção do leitor, sendo que a primeira discorria sobre o trabalho institucional de uma escola especial brasileira, ao passo que a segunda era a transcrição de um artigo publicado na revista estadunidense Columbia, de Nova York. Implicitamente, os editores sugeriam que, se nos Estados Unidos a profissionalização de excepcionais estava se convertendo em um investimento profícuo aos cofres públicos e particulares, o mesmo deveria ser estendido ao Brasil, nas práticas de educação e ajustamento desse público. Afinal, tendo um emprego remunerado, os retardados "[...] ajudariam a economia e a pagar os impostos e ao mesmo tempo enriquecer o empregador por ter um pessoal digno de confiança e incansavelmente produtivo" (CONNIFF, 1963, p. 12, grifos nossos). Eis a mensagem que as Apaes federadas tanto queriam propagar em seu periódico:

Figura 5 - Matérias apresentadas lado a lado, respectivamente sobre uma escola especial brasileira e sobre o trabalho de retardados em fábrica de brinquedos estadunidense.

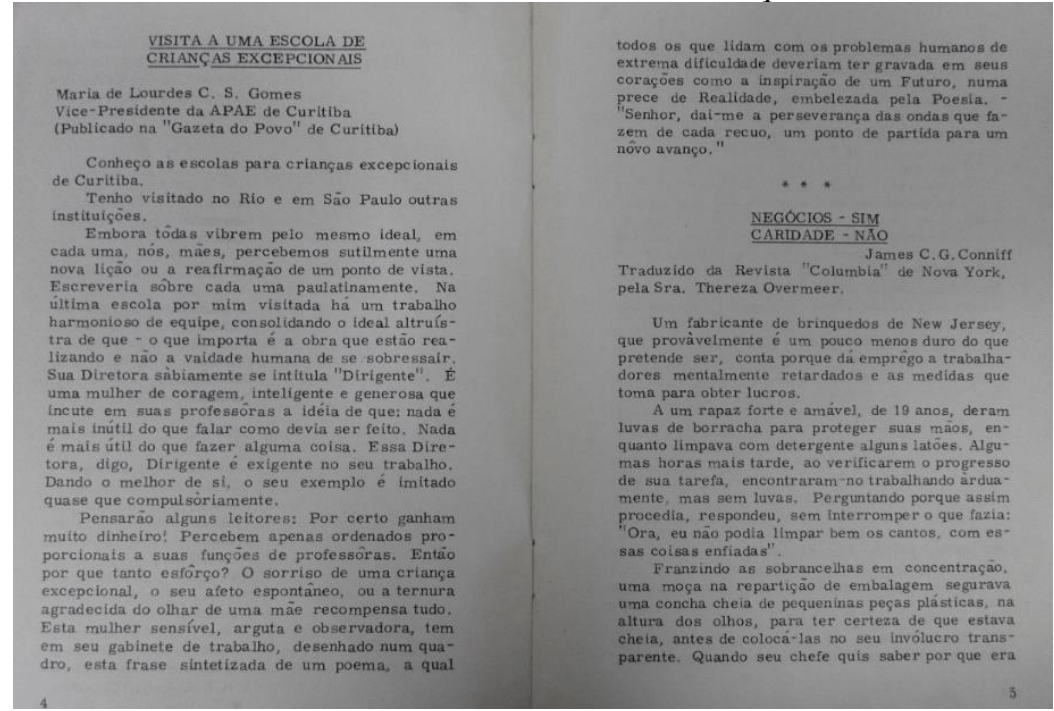

Fonte: Mensagem da Apae (v. I, n. 6, p. 4-5, 1963).

Essa estratégia editorial fazia parte dos objetivos da Federação Nacional das Apaes quanto às suas pretensões de convencer o empresariado e toda a sociedade a aceitar a mão de obra do excepcional, tentando provar que esta seria lucrativa para as empresas e que "Mesmo na moderna sociedade industrial, muitas são as atividades que podem ser executadas pelos retardados mentais primários [...]" (BORRAIZ, 1964, p. 44). Consequentemente, os apaeanos tentavam representar o trabalho do deficiente não como mera caridade, mas como um negócio lucrativo para os empregadores e para o bem-estar social (Figura 5), pois "Amparado com um trabalho, sobretudo se protegido, ele [o excepcional] deixará de constituir um problema para a sociedade" (COMO SURGE..., 1963, p. 12), desde que "[...] lhes seja prestada assistência adicional no tocante à educaşão de que precisam para maior produtividade" (BORRAIZ, 1964, p. 44, grifos nossos). Foi exatametente para viabilizar essa assistência educacional aos excepecionais, com o propósito de “[...] oferecer oportunidades de treinamento e preparo para o emprego [...]" (PEREIRA, [1972?], p. 31), que as Apaes investiram, ainda, na instalação de oficinas pedagógicas para os deficientes mentais adolescentes e adultos, como corolário de seu programa educativo e de sua identidade institucional. No auge do tecnicismo pedagógico e político-econômico daqueles tempos, as oficinas constituíam 
[...] o coroamento do ensino especializado. Destinam-se aos egressos das classes especiais, dos centros especiais, portadores do Certificado de Alfabetização.

Elas devem habilitar os adolescentes, de acordo com suas capacidades e com as necessidades regionais, em função do mercado de trabalho.

Essas oficinas devem ser dirigidas por mestres especializados ou então com a supervisão de professores especializados e mestres comuns (SUBSÍDIOS..., 1973, p. 85, grifos nossos).

Nesse ponto, é mister lembrar que, já nas suas origens, tal formato educativo fora preconizado pela Apae. No Rio de Janeiro, com a fundação da primeira escolinha da entidade, os apaeanos perceberam que seria preciso avançar na educação dos excepcionais, pensando-se em alternativas pedagógicas para os deficientes mais velhos ou para aqueles que concluíam o ciclo primário de atividades da escolinha. Surgiu, então, em 1958, o Centro de Aprendizagem Ocupacional da Apae carioca, inicialmente com apenas uma oficina pedagógica para adolescentes, a de carpintaria, cujas práticas passaram a ser modelares para as outras Apaes que foram surgindo nos anos de 1950 a 1970. Esse Centro também se expandiu e, no final da década de 1960, orgulhava-se de "[...] proporcionar ao adolescente uma educação integral, seu ajustamento ao meio social, preparando-o para o trabalho competitivo ou protegido e, ainda, ocupação para os que não atingiram a fase do trabalbo sistematizado" (A APAE..., 1968, p. 8, grifos nossos), isto é, para aqueles com retardo mental mais severo. Para essa finalidade, diversas oficinas foram criadas, segundo foi divulgado em Mensagem da Apae, nesta página:

Figura 6 - Oficinas do Centro de Aprendizagem Ocupacional da Apae carioca na década de 1960.

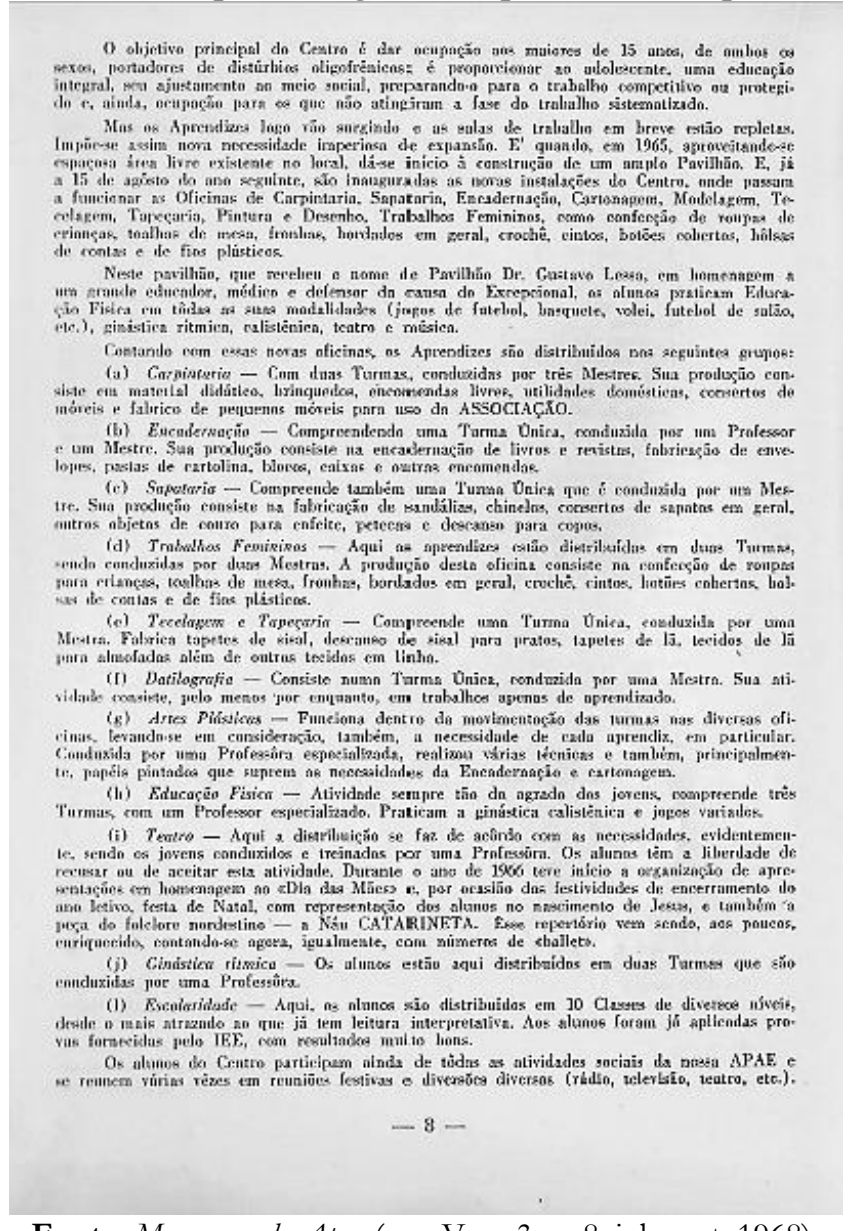

Fonte: Mensagem da Apae (ano V, n. 3, p. 8, jul. - set. 1968).

$\mathrm{Na}$ compreensão apaeana, essas oficinas eram a grande esperança de integração social e aprendizagem do deficiente, pois representavam "[...] o elo, cuja falta hoje se sente, entre as atividades escolares e a vida profissional [...]" (NOTICIÁRIO, 1965, p. 38). Uma vida profissional que, todavia, para o retardado, já vinha pré-definida, simulada e estipulada de acordo com supostos níveis de sua idade 
mental, conforme fez questão de divulgar Mensagem da Apae em [1972?], cujas páginas correlatas são reproduzidas logo adiante ${ }^{17}$, para melhor compreensão das práticas pedagógicas apaeanas e, por extensão, do "ensino" especializado de outrora (Figura 7). Mesmo assim, há que se ponderar que essa era, para os agentes apaeanos, a solução mais viável que tanto buscavam para o problema do excepcional. As oficinas pedagógicas ocupavam o retardado, eram um espaço para sua socialização, afastavam-no da "delinquência", liberavam a força de trabalho dos seus pais, disciplinavam-no e incutiam-lhe hábitos salubres, podendo vir até mesmo a render-lhe alguma chance de emprego, se aprendesse um "ofício".

Figura 7 - Ocupações para meninos e meninas com retardo mental, conforme sua idade mental.
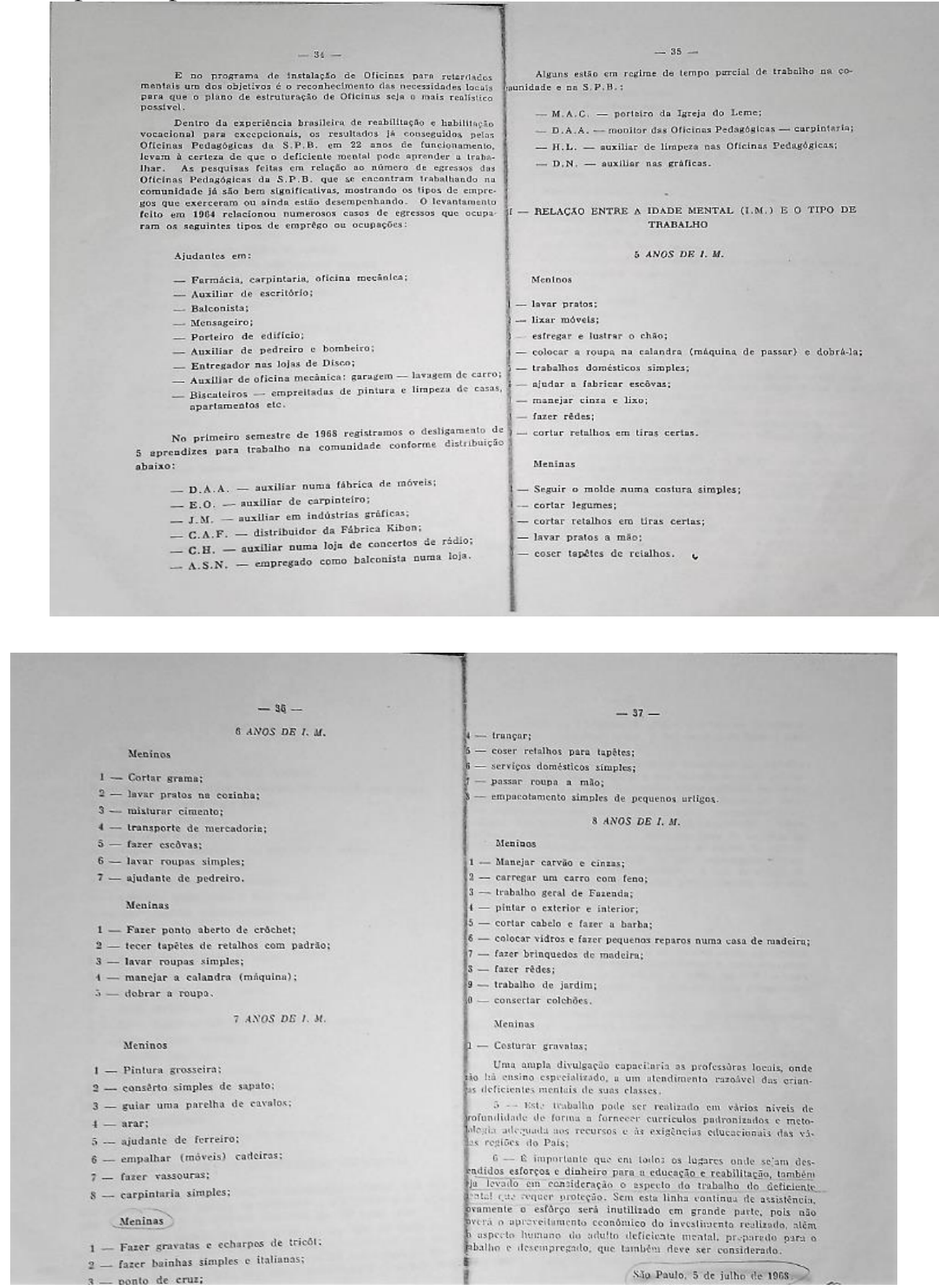

Fonte: Mensagem da Apae (p. 34-38, [1972?]).

Vale ressaltar, ainda, que tais oficinas podiam ser chamadas de pedagógicas, quando apenas visavam ao ensino de técnicas e habilidades ocupacionais para futura inserção profissional do deficiente mental no trabalho competitivo; ou protegidas, frequentadas por excepcionais com algum preparo

\footnotetext{
${ }^{17}$ Em relação às ocupações pré-definidas para os retardados mentais, nos anos de 1960 a 1970, como se pode ver pela Figura 7, havia distinção não só quanto à sua possível idade mental, mas, também, em relação ao seu gênero, o que, por ora, não nos propomos a discutir. 
profissional, geralmente obtido na própria oficina pedagógica. Estes, por não se adaptarem às condições laborais fora da instituição especial ou sequer dela tendo saído, devido às suas "limitações" intrínsecas, passavam a executar determinado ofício, sob supervisão, em tais oficinas, também apelidadas de "abrigadas". Em várias edições de Mensagem da Apae, o assunto veio à tona, a fim de convencer o leitor da racionalidade e legitimidade da proposta, com base em argumentos economicistas, como nos excertos que reproduzimos em seguida:

\begin{abstract}
Industriais e comerciantes, deem um lugar ao menor abandonado. [...]. Ao excepcional confiem trabalhos nas Oficinas Protegidas. Estas funcionam junto às APAEs com pessoal especializado e podem, perfeitamente, [...] contratar certos trabalhos em que as Empresas também se beneficiam e, além disso, uma solução está sendo dada ao problema do excepcional.

As Oficinas Protegidas poderão garantir o ganha-pão do excepcional se os srs. industriais e os srs. comerciantes de visão a elas confiar trabalhos que serão realizados, com ou sem fiscalização, conforme a natureza da tarefa e o nivel do atraso individual (COMO SURGE..., 1963, p. 12-13, grifos nossos).
\end{abstract}

Se é verdade que a instalação e manutenção de tais oficinas acarretam despesa considerável, já foi comprovado por pesquisas idôneas que essa despesa representa, na verdade, um investimento. Os recursos aplicados nas oficinas protegidas voltam não só através do produto do trabalho dos deficientes, mas também indiretamente, pela libertação da mão de obra, muitas vezes de alta qualidade, dos responsáveis pelo deficiente, a qual permanecia inativa, pela necessidade de dispensar cuidados constantes ao excepcional.

Destinam-se as oficinas protegidas a possibilitar trabalho a pessoas para tanto já capacitadas, mas cuja deficiência as impede de integrar, no momento ou para sempre conforme o caso, o mercado competitivo de mão de obra, porque necessitam permanecer sujeitas a processo especializado de supervisão (GONÇALVES, 1968b, p. 12).

Essas oficinas protegidas aceitavam encomendas e pedidos de empresas e funcionavam, quase sempre, como estruturas anexas às escolas e instituições especializadas, inclusive das Apaes, como se depreende pelos fragmentos apelativos retirados de seu periódico oficial. Podiam, assim, gerar algum lucro para as instituições apaeanas se manterem, haja vista seu caráter filantrópico, bem como significavam espaço de continuar a "formação" e modelagem profissional dos assistidos pelas Apaes, o que evidencia o caráter inventivo das práticas educacionais apaeanas em resposta às demandas daquele contexto. Todavia, como efeito, essas mesmas oficinas tornavam-se, também, uma forma de prolongar a segregação dos excepcionais e de mantê-los em condições artificiais de vida e ocupação, sob o argumento de que deixavam de ser, na ótica apaeana, elementos de perturbação social. Notamos, aqui, as práticas de representação operando como estratégia de convencimento da sociedade e de cooptação de adeptos à causa apaena. Esta tomava de empréstimo ao capitalismo que se intensificava no Brasil a imagem do excepcional operário e ordeiro, o que fornecia uma chave para entender os esforços educacionais das Apaes federadas, as quais, como instituições, agiam conforme as circunstâncias de seu tempo, enquanto buscavam assumir um papel de destaque em seu campo de atuação, fazendo crer que, moralmente, eram instituições capazes de empreender a adaptação laboral e social do retardado pelo e para o trabalho. Ao procederem assim, instituíam sua missão e sua razão de ser.

Como naquele contexto dos anos de 1960 a 1970, o excepcional ainda era visto como problema nacional e risco à higidez social, desacreditado em suas possibilidades educacionais e esquecido pelo governo, as Apaes tornaram-se, justamente, produtoras e difusoras dessa representação que o caracterizava como um sujeito apto a formas de produção e, portanto, como partícipe das relações sociais de trabalho capitalistas, o que, pelo menos, abria determinado caminho para justificar e direcionar as práticas pedagógicas de que lançavam mão e que confiscavam como seu próprio (CERTEAU, 1994). Tais instituições colocaram-se, então, no campo das lutas de representação, fornecendo à sociedade e ao poder público uma outra imagem representativa da "excepcionalidade", diferente daquela que era recorrente, qual seja, da completa inaptidão e dependência do excepcional. Temos aí um lance estratégico que, corolariamente, permitia ao apaenos isolar e demarcar um lugar nesse campo, isto é, "[...] um serpercebido constitutivo de sua identidade" (CHARTIER, 1991, p 184).

Destarte, tais formulações discursivas, materializadas no impresso apaeano, tinham um potencial muito mais estratégico, inventivo e simbólico, a fim de se justificar a educação dos excepcionais 
perante a opinião pública, e de se forjar uma representação favorável em torno do tema e dessas instituições, ainda em fase de expansão nacional, do que um resultado econômico significativo propriamente dito. Não era esse resultado, aliás, que interessava às Apaes, mas a sensibilidade provocada pela representação que se queria veicular no e pelo impresso, com a publicação de tais informações, mediante os arranjos editoriais apresentados. Isso porque, como se pôde verificar, não obstante a defesa apaeana, o trabalho ensinado e praticado nessas oficinas, bem como nas escolas especiais das Apaes, assumia um caráter semiprofissional, desqualificado e repetitivo, sendo que ao excepcional só eram "[...] remetidas as tarefas que não se mostra[va]m lucrativas para o operário 'normal', além do baixo salário" (JANNUZZI, 1992, p. 58) atribuído como remuneração pelo serviço dos deficientes. Já nas décadas de 1960 e 1970, essa proposta pouco se sustentava empiricamente, conquanto fosse estratégico seu apelo simbólico para a própria configuração, manutenção e divulgação da identidade institucional das Apaes federadas, no campo da excepcionalidade. Em certo sentido, isso ocorria devido à própria modernização urbano-industrial do País, que tornava superado o foco pedagógico em atividades artesanais e de simples "adestramento" manual, porquanto se ia consolidando um Brasil, eterno candidato a grande potência, no qual "[...] as mercadorias consumidas [eram] [...] principalmente as de cunho industrial e não artesanal, pois que estas são [eram] de difícil colocação no mercado [...]” (JANNUZZI, 1992, p. 55).

De outro ângulo, perante o avanço do capitalismo, “[...] com métodos e técnicas de trabalho que não ocupa[va]m toda a nossa mão de obra, há[via] competição para se entrar no mercado de trabalho em detrimento não só dos 'deficentes', mas também de parte considerável da população considerada 'normal”' (JANNUZZI, 1992, p. 53). Não era essa, porém, a leitura feita pelos apaeanos, até porque a institucionalização do deficiente mental pelas oficinas protegidas colovava-se como a consequência do empreendimento educativo das Apaes. Isso leva a pensar que, para além de ser um espaço de produção de mercadorias, prestação de serviços à comunidade ou de "[...] formação de hábitos para os deficientes mentais severos, [...] [e] ensino de tarefas e trabalhos semiprofissionais [...] para os educáveis" (SUBSÍDIOS..., 1973, p. 89), tais oficinas eram, sobretudo, no sentido comeniano, oficinas de homens, isto é, tempos e espaços de modelagem do excepcional, de harmonização de seus sentidos e de "conserto" de suas supostas falhas naturais. Assim, só conseguimos entender essa defesa pelo trabalho do excepcional como algo lucrativo se, na verdade, observarmos as representações que se cruzavam naquele momento em torno dessa problemática. Educar esse sujeito, ainda que pela via de atividades artesanais, dava-lhes mais autonomia nas atividades de vida diária e permitia liberar os pais e familiares para o trabalho e para o consumo nas cidades, com sua vida cada vez mais agitada, propiciando, desse modo, a higiene mental familiar e social, como os apaeanos defendiam. Esse argumento era complementado pela ideia de que, estando os excepcionais ocupados, o Brasil se beneficiaria com a "[...] libertação da mão de obra, muitas vezes de alta qualidade, dos responsáveis pelo deficiente, a qual permanecia inativa, pela necessidade de dispensar cuidados constantes ao excepcional” (GONÇALVES, 1968a, p. 12).

Por isso, sua educação não era mesmo um processo consistente de profissionalização, mas de prevenção a possíveis distúrbios e gastos que viesse a causar. Era uma educação para a higiene social, cujo fito, mais do que formar o cidadão, era impedir a emergência do delinquente, entendido, na época, como todo aquele que, por assim dizer, fosse um não trabalhador ou um desocupado, conforme o quadro representacional do capitalismo e do moralismo então imperante. Como se posicionaram os apaeanos no III Congresso Nacional das Apaes, em 1967,

[...] a inoperância na assistência ao excepcional ou ao desajustado social provocará o aparecimento de mais delinquentes na vida nacional. Deste modo, bem mais interessante se torna a formação do caráter, dentro de características especiais, do que ter de manter Colônias Correcionais, e mesmo que se atinja esse ponto, se procure então recuperar, dentro dos moldes técnicos, o desajustado, a fim de que tenha condições de vir a ser útil à comunidade (III CONGRESSO..., 1968, p. 26, grifos nossos).

Mediante o exposto, como reproduzido anteriormente, a partir de páginas de Mensagem da Apae, no programa educacional dessas oficinas e escolas especializadas, apesar do constante discurso de educação integral, não se dava, para efeito de comparação, “[...] prosseguimento a um trabalho pedagógico sistematizado que amplie a visão de mundo do 'deficiente' através do prosseguimento da educação física, 
musical, artística, da alfabetização, da educação sexual, manipulação de dinheiro, conhecimento de hora, etc.” (JANNUZZI, 1992, p. 58), saberes que se impunham como imprescindíveis já naquela conjuntura. O resultado era uma integração precária e subordinada do deficiente mental, que, embora pudesse vir a ter uma ocupação prática, nem sempre identificada com emprego ou, menos ainda, com trabalho, continuava sendo um cidadão pela metade, com poucas chances de desenvolvimento cognitivo e de usufruto de uma educação formal, pautada no "[...] saber sistematizado, através de teoria da aprendizagem adequada, concretizada em métodos e técnicas eficazes” (JANNUZZI, 1992, p. 61). Nesse sentido, observamos que o foco, por esse período, era principalmente instituir a "[...] Federação enquanto lugar para o atendimento dos 'excepcionais', muito mais do que garantir o acesso deles à educação. Esse acesso vinha depois que se garantissem as condições da existência institucional, sendo oferecido de acordo com as necessidades dessa manutenção" (RAFANTE; SILVA; CAIADO, 2019, p. 15).

\section{CONSIDERAÇÕES FINAIS}

Ao longo deste artigo, buscamos explicitar que, para os apaeanos, nas tensões da realidade vivida, diante das dificuldades existentes, das estratégias a serem mobilizadas e das muitas urgências que os afligiam, como agentes educacionais que eram, também, pais e amigos dos excepcionais, o principal desafio a ser enfrentando era "[...] alcançar o êxito no desabrochamento, no amadurecimento e na adaptação da criança [com deficiência mental]" (CAETANO, 1966, p. 21). Para esse propósito, valiam as práticas e representações daquela que ora designamos como Pedagogia do Ajustamento Social, cujo lema assim poderia ser traduqido: (re)habilitar, treinar e ajustar o excepcional à sociedade - porém não o contrário -, educando-o sob o invólucro material e simbólico produzido a partir da ideia geradora de mais amor e compreensão para o "deficiente", tal como evocado pela imagem-símbolo da Federação Nacional das Apaes: uma flor margarida protegida por duas mãos em perfil. Essa imagem reforçava o poder da representação forjada em torno do excepcional, que não podia falar, mas era "falado"; que não criava a cena, mas era nela colocado por outrem; que não escolhia sua ocupação laboral ou sua forma de educação, mas estava a elas destinado conforme seu suposto "nível" de retardo. Assim como a flor, ele era um ser delicado, sendo, em si mesmo, uma mensagem ao mundo, evocando ternos sentimentos. Todavia, para que esse mesmo ser se concretizasse, era mister que alguém o cultivasse, retirando-o do isolamento, da "inutilidade" e da vida desfavorável, que poderia levá-lo à desocupação e delinquência. Por isso, carecia de ser educado, tutelado e amparado em um ambiente especializado, como as oficinas e escolas das Apaes, haja vista sua inocência e presumida fragilidade. Dessa forma, deixavam, também, de representar um "problema" para suas famílias e se tornavam uma questão da instituição especializada e de seus agentes, à medida que eram "confiscados" a esse lugar de modelagem social.

Tanto que, pela organização material e textual do impresso Mensagem da Apae, evidenciamos o investimento discursivo das Apaes federadas como forma de legitimar sua identidade institucional e justificar seu trabalho educativo voltado para esse público excepcional, em um período no qual começavam a ocupar um espaço de poder nas relações sociais e político-educacionais, mediante a organização de um saber-fazer que era difundido como seu próprio (CERTEAU, 1994). Talvez tenha sido essa a principal mensagem pedagógica das Apaes desde seus primórdios, a qual, por meio das múltiplas chaves de leitura permitidas pelos primeiros números impressos de seu mais antigo periódico, buscamos (re)ler, compreender e (de)cifrar, uma vez que tal mensagem repercute, ainda de modo intenso, nas formas como se tem praticado e representado a educação de pessoas com deficiência no cenário educacional brasileiro. Parece que persiste a ideia de que a pessoa com deficiência intelectual, ainda hoje, não precisa ser escolarizada formalmente, mas apenas ocupar o tempo em uma atividade qualquer para que não cause transtornos à sociedade ou à dinâmica escolar. Podemos dizer, aliás, que esse impresso muito contribuiu, em sua forma e conteúdo, para também "[...] disseminar o consenso de que a APAE é o lugar da deficiência intelectual, o que permanece até a atualidade e dificulta a constituição de políticas públicas e a garantia dos direitos das pessoas com deficiência" (RAFANTE; SILVA; CAIADO, 2019, p. 15). Reconhecer e problematizar a permanência dessa representação, no bojo das rupturas políticopedagógicas hodiernas, quando se defende um modelo escolar inclusivo, é, pois, a tarefa que se coloca para a educação contemporânea, na configuração de novas práticas e representações educacionais. 


\section{REFERÊNCIAS}

1. BEZERRA, Giovani Ferreira. A Federação Nacional das Apaes e seu periódico (1963-1973): estratégias, mensagens e representações dos apaeanos em (re)vista. 2017. 340 f. Tese (Doutorado em Educação) - Faculdade de Educação, Universidade Federal da Grande Dourados, Dourados, 2017. Disponível em: http://files.ufgd.edu.br/arquivos/arquivos/78/MESTRADODOUTORADO-EDUCACAO/Tese\%20Final-\%20Giovanni\%20Ferreira.pdf. Acesso em: 27 fev. 2018.

2. BEZERRA, Giovani Ferreira; FURTADO, Alessandra Cristina. A produção sobre História da Educação Especial nos Congressos Brasileiros de História da Educação (CBHEs): um lugar em construção. Educação em Revista, Belo Horizonte, n. 33, 2017. Disponível em: http://www.scielo.br/pdf/edur/v33/1982-6621-edur-33-156559.pdf. Acesso em: 22 set. 2017.

3. BRASIL. Lei de Diretrizese e Bases da Educação Nacional. LDB 9.394, de 20 de dezembro de 1996. Disponível em: http://www.planalto.gov.br/ccivil_03/leis/L9394.htm. Acesso em: 06 set. 2011.

4. BRASIL. Decreto-lei n. 2.024, de 17 de fevereiro de 1940. Fixa as bases da organização da proteção à maternidade, à infância e à adolescência em todo o país. Não paginado. Disponível em: http:/ /legis.senado.gov.br/legislacao/ListaTextoIntegral.action?id=25156\&norma=40602. Acesso em: 31 mar. 2017.

5. BRASIL. Lei n. 4.024, de 20 de dezembro de 1961. Fixa as Diretrizes e Bases da Educação Nacional. Disponível em: http://www6.senado.gov.br/legislacao/ListaPublicacoes.action?id=102346. Acesso em: 18 set. 2011.

6. BUENO, José Geraldo Silveira. Educação especial brasileira: integração/segregação do aluno diferente. 2. ed. rev. São Paulo: Educ, 2004.

7. CARVALHO, Marta Maria Chagas. Apresentação. In: BICCAS, Maurilane de Souza. O impresso como estratégia de formação: Revista do Ensino de Minas Gerais (1925-1940). Belo Horizonte: Argvmentvm, 2008. p. 11-14.

8. CERTEAU, Michel de. A invenção do cotidiano: artes de fazer. Petrópolis: Vozes, 1994.

9. CHARTIER, Roger. A História Cultural: entre práticas e representações. 2. ed. Lisboa: Difel, 1990.

10. CHARTIER, Roger. O mundo como representação. Estudos Avançados, São Paulo, v.5, n. 11, p. 173-191, 1991. Disponível em: http://www.usp.br/cje/anexos/pierre/CHARTIER O mundocomorepresentacao.pdf. Acesso em: 22 jun. 2014.

11. CHARTIER, Roger. Inscrever \& apagar: cultura escrita e literatura (séculos XI-XVIII). São Paulo: Unesp, 2007.

12. CHARTIER, Roger. Os desafios da escrita. São Paulo: Unesp, 2002.

13. DALLABRIDA, Adarzilse Mazzuco. As famílias com filhos deficientes e a escolha da escola: o caso do Colégio Coração de Jesus. 2006. 192 f. Tese (Doutorado em Educação) - Pontifícia Universidade Católica de São Paulo, São Paulo, 2006. Disponível em: https://sapientia.pucsp.br/handle/handle/10500. Acesso em: 21 maio 2017.

14. DRUMOND, Adriana Cláudia. A Associação de Pais e Amigos dos Excepcionais de Barbacena e o atendimento às pessoas com sindrome de Down (1962-1976): diálogos com pestalozzianos. 2015. $192 \mathrm{f}$. Tese (Doutorado em Educação, Conhecimento e Inclusão Social) - Faculdade de Educação, Universidade Federal de Minas Gerais, Belo Horizonte, 2015. Disponível em: http://www.bibliotecadigital.ufmg.br/dspace/bitstream/handle/1843/BUBD-

A3NJN4/tese_adriana_cl_udia_drumond.pdf?sequence=1. Acesso em: 16 dez. 2016.

15. HISTÓRIA: Fenapaes, rede Apae e sua História. In: Apae Brasil, 2018. Disponível em: https://apaebrasil.org.br/page/2. Acesso em: 27 ago. 2018.

16. FERREIRA JÚNIOR, Amarilio; BITTAR, Marisa. Educação e ideologia tecnocrática na ditadura militar. Cadernos Cedes, Campinas, v. 28, n. 76, p. 333-355, set. - dez. 2008. Disponível em: Acesso em: http://www.scielo.br/pdf/ccedes/v28n76/a04v2876. Acesso em: 19 maio 2015. 
17. GATTI JÚNIOR, Décio. A pedagogia tecnicista no contexto brasileiro do Golpe Militar de 1964: o projeto educacional do Instituto de Pesquisa e Estudos Sociais (1961-1972). Cadernos de História da Educação, Uberlândia, v. 9, n. 1, p. 45-63, jan.- jun. 2010. Disponível em: http://www.seer.ufu.br/index.php/che/article/view/7451/4768. Acesso em: 19 maio 2017.

18. HISTORY of the ARC. In: The ARC: for people with intellectual and developmental disabilities. Washington D.C., 2016. Disponível em: http://www.thearc.org/who-we-are/history. Acesso em: 30 mar. 2017.

19. JANNUZZI, Gilberta Sampaio de Martino. Oficina obrigada e a "integração" do "deficiente mental". Revista Brasileira de Educação Especial, Piracicaba, v. 1, n. 1, p. 51-63, 1992. Disponível em: http://www.abpee.net/homepageabpee04_06/artigos_em_pdf/revista1numero1pdf/r1_art05. pdf. Acesso em: 30 maio 2017.

20. JANNUZZI, Gilberta de Martino; CAIADO, Katia Regina Moreno. APAE - 1954 a 2011: algumas reflexões. Campinas: Autores Associados, 2013.

21. KASSAR, Mônica de Carvalho Magalhães. Deficiência múltipla e educação no Brasil: discurso e silêncio na história de sujeitos. Campinas: Autores Associados, 1999.

22. LE GOFF, Jacques. História \& Memória. 7. ed. rev. Campinas: Unicamp, 2013.

23. LEHMKUHL, Márcia de Souza. A Reconfiguração da Federação Nacional das Apaes (Fenapaes) no Estabelecimento da Relação entre Público e Privado nas Políticas de Educação Especial (1974-2006). 2018. 173f. Tese (Doutorado em Educação) - Pontifícia Universidade Católica de São Paulo, São Paulo, 2018.

24. PALACIOS, Guillermo. Intimidades, conflitos e reconciliações: México e Brasil, 1822-1993. São Paulo: Edusp; SRE, 2008.

25. PRIORI, Angelo et al. A Ditadura Militar e a violência contra os movimentos sociais, políticos e culturais. In: História do Paraná: séculos XIX e XX. Maringá: Eduem, 2012. p. 199-213.

Disponível em: http://books.scielo.org/id/k4vrh/pdf/priori-9788576285878-15.pdf. Acesso em: 18 dez. 2016.

26. RAFANTE, Heulalia Charalo. Helena Antipoff, as Sociedades Pestalozzi e a Educaşão Especial do Brasil. 2011. 311f. Tese (Doutorado em Educação) - Centro de Educação e Ciências Humanas, Universidade Federal de São Carlos, São Carlos, 2011.

27. RAFANTE, Heulalia Charalo; SILVA, João Henrique da; CAIADO, Katia Regina Moreno. A Federação Nacional das Apaes no contexto da ditadura civil-militar no Brasil: construção da hegemonia no campo da educação especial. Arquivos analíticos de políticas educativas/ Education Policy Analysis Archives, v. 27, n. 64, p. 01-22, 2019. Disponível em: https://epaa.asu.edu/ojs/article/view/4474/2263. Acesso em: 23 out. 2019.

28. SILVA, Juremir Machado da. Anjos da Perdição: futuro e presente na cultura brasileira. Porto Alegre: Sulina, 1996.

29. SILVA, João Henrique da. Federação Nacional das Apaes no Brasil, hegemonia e propostas educacionais (1990-2015). 2017. 384f. Tese (Doutorado em Educação Especial) - Centro de Educação e Ciências Humanas, Universidade Federal de São Carlos, São Carlos, 2017.

Textos de Mensagem da Apae

30. A APAE em treze anos de atividades. Mensagem da Apae, São Paulo, ano V, n. 3, p. 3-14, jul. - set. 1968.

31. ALVES, Edy Pinheiro. Pesquisa de escolaridade em alunos excepcionais. Mensagem da Apae, São Paulo, ano II, n. 3, p. 11-12, jul. - dez. 1964.

32. APAE do Recife. Mensagem da Apae, São Paulo, v. 1, n. 6, p. 19-20, 1963.

33. BERCHT, Ula. Mensagem da Escola Especial Municipal "Recanto do Amor e Compreensão". Mensagem da Apae, São Paulo, ano IV, n. 1 a 4, p. 28-29, jan. - dez. 1966.

34. BORRAIZ, Nelci. O problema do excepcional e sua parcial solução. Mensagem da Apae, São Paulo, ano II, n. 2, p. 43-44, abr. - jun. 1964.

35. CAETANO, José Gomes. Considerações metodológicas no tratamento da deficiência mental. Mensagem da Apae, São Paulo, ano IV, ns. 1 a 4, p. 20-22, jan. - dez. 1966. 
36. COMO SURGE uma Associação de Pais e Amigos dos Excepcionais? Mensagem da Apae, São Paulo, v. 1, n. 5, p. 8-13, 1963.

37. CONNIFF, James C. G. Negócios - sim; Caridade - não. Mensagem da Apae, São Paulo, v. 1, n. 6, p. 5-12, 1963.

38. FLORENZANO, Rosa. Grupo de Trabalho ABDM/CADEME: Educação e Reabilitação. Mensagem [da Apae]: Federação Nacional das Apaes, Belo Horizonte: Imprensa Oficial, p. 19-26, [1972?].

39. GONÇALVES, Nair Lemos. A criança excepcional e o direito à educação. Mensagem da Apae, São Paulo, ano V, n. 3, p. 28-30, jul. - set. 1968a.

40. GONÇALVES, Nair Lemos. A Previdência Social e a Reabilitação dos deficientes mentais. Mensagem da Apae, São Paulo, vol. 1, n. 2, p. 33-36, abr. - jun. 1964.

41. GONÇALVES, Nair Lemos. O excepcional e o trabalho. Mensagem da Apae, São Paulo, ano V, n. 4, p. 9-12, out. - dez. 1968b.

42. II CONGRESSO da Federação Nacional das Apaes. Mensagem da Apae, São Paulo, ano III, n. 1 a 4, p. 41-43, jan.- dez. 1965.

43. III CONGRESSO Nacional das Apaes: Curitiba - Paraná - 4 a 9 de julho de 1967: organização de fundos e campanhas financeiras. Mensagem da Apae, São Paulo, ano V, n. 3, p. 25-27, jul. - set. 1968.

44. KRYNSKI, Stanislau. Tarefa da Comissão Cientifica. Mensagem da Apae, São Paulo, v. II, n. 2, p. 2- 6, 1963.

45. KRYNSKI, Stanislau. Reflexões em torno da criança excepcional e suas relações com a sociedade. Mensagem da Apae, São Paulo, ano II, n. 1, p. 9-18, jan. - mar. 1964.

46. MENSAGEM da Apae. APAE Brasil: 60 anos. Brasília: Federação Nacional das APAEs, ano 47, n. 01, nov. 2014.

47. NOTÍCIA. Mensagem da Apae, São Paulo, v. 1, n. 3, p. 9-11, 1963.

48. NOTICIÁRIO: diversos. Mensagem da Apae, São Paulo, ano III, ns. 1 a 4, p. 38-39, jan.- dez. 1965.

49. NOTICIÁRIO: Federação das Apaes [diversos]. Mensagem da Apae, São Paulo, ano II, n. 1, p. $25-$ 30, jan. - mar. 1964.

50. OBJETIVOS da Federação Nacional das Apaes. Mensagem da Apae, São Paulo, ano II, n. 1, p. 4, jan. - mar. 1964.

51. PEREIRA, Justino Alves. Editorial. Mensagem [da Apae]: Federação Nacional das Apaes, Belo Horizonte: Imprensa Oficial, p. 5, [1972?].

52. PEREIRA, Justino Alves. Conversa com o leitor. Mensagem da Apae, São Paulo, ano 9, n. 29, p. 2, jul.- set. 1982.

53. PEREIRA, Olívia. O excepcional no mundo do trabalho. Mensagem da Apae, São Paulo, ano II, n. 4, p. 14-15, out. - dez. 1964.

54. PEREZ-RAMOS, Aidyl M. de Queiroz. Retardados mentais, treináveis e dependentes. Mensagem da Apae, São Paulo, ano IV, ns. 1 a 4, p. 15-16, jan. - dez. 1966.

55. RABELO, Armando. Mensagem da Apae, São Paulo, ano II, n. 2, p. 47-49, abr. - jun. 1964.

56. ROCHA LAGOA, Francisco de Paula. Discurso pronunciado pelo Exmo. Sr. Ministro da Saúde, Dr. Rocha Lagoa. Revista Mensagem [da Apae], Belo Horizonte: Imprensa Oficial, p. 37-38, 1973.

57. SCHILLING, Telmo Ignácio. Mensagem da Apae, [S.1.], ano VI, n. 5, p. 31-37, out.- dez. 1969.

58. SEIXAS, Nelson de Carvalho. Interação entre pais e técnicos. Mensagem da Apae, [S.1.], ano VI, n. 5, p.145-149, out. - dez. 1969.

59. SUBSÍDIOS para um Plano Nacional de Combate à Deficiência Mental (1967). Mensagem da Apae, Belo Horizonte, p. 41-155, 1973.

60. XAVIER, Maria Amélia Vampré. A formação de novas Apaes. Mensagem da Apae, São Paulo, v. 1, n. 3, p. $2-4,1963$.

Submetido: $11 / 04 / 2019$ 
Aprovado: $14 / 02 / 2020$ 